\title{
Microstructures of epidote-prehnite bearing damaged granitoids (northern Victoria Land, Antarctica): clues for the interaction between faulting and hydrothermal fluids
}

\author{
Cristina Malatesta ${ }^{\mathrm{a}}$, Laura Crispini ${ }^{\mathrm{a},{ }^{*}}$, Benoit Ildefonse ${ }^{\mathrm{b}}$, Laura Federico ${ }^{\mathrm{a}}$, Frank Lisker ${ }^{\mathrm{c}}$, \\ Andreas Läufer ${ }^{\mathrm{d}}$ \\ ${ }^{a}$ Department of Earth Sciences, Environment and Life (DISTAV), University of Genova, C.so Europa 26, 16132, Genova, Italy \\ ${ }^{\mathrm{b}}$ Géosciences Montpellier, University of Montpellier, CNRS, Université des Antilles, Montpellier, France \\ ${ }^{\mathrm{c}}$ Universität Bremen, FB 5 Geowissenschaften, Klagenfurter Str. 2, 28359, Bremen, Germany \\ ${ }^{\mathrm{d}}$ Federal Institute for Geosciences and Natural Resources (BGR), Stilleweg 2, 30655, Hannover, Germany
}

\begin{abstract}
A B S T R A C T
Exhumed faults in granitoids along the Lanterman Fault-Rennick Graben Fault system (northern Victoria Land, Antarctica) show superposed ductile to brittle deformation and pervasive hydrothermal fluid-rock interaction. These processes triggered multiple brittle slip events producing crosscutting epidote and prehnite-rich fault veins, ultracataclasites and pseudotachylytes of crushing origin. Combined microstructural and minerochemical investigations on fault damage zones show three types of alteration: (i) albitization of K-feldspar and Caplagioclase; (ii) crystallization of prehnite and calcite in veins; (iii) alteration of magmatic phases by secondary hydrous minerals (e.g. chlorite, white mica, epidote and prehnite). The fault experienced various episodes of strain weakening and hardening, due to alteration of minerals and precipitation of epidote and prehnite within ultracataclastic intervals, at decreasing temperature conditions $\left(200<\mathrm{T}^{\circ} \mathrm{C}<450\right)$ and varying $\mathrm{CO}_{2}$ fugacity of the fluids. Cyclic crystallization of epidote/prehnite within the fault cores caused cementation and locking of faults, concentration of deformation at weaker horizons and a progressive broadening of the fault zone. Our results indicate that multiple co-seismic slip and syntectonic fluid flow very likely occurred prior to the Cenozoic brittle reactivation of inherited anisotropies in the northern Victoria Land crust along the Lanterman FaultRennick Graben Fault system and underlines its high potential for polyphasicity.
\end{abstract}

\section{Introduction}

The presence of mineralization after fluid-rock interaction within fault rocks plays an important role both on fault permeability and on fault mechanics (e.g. seismic vs. aseismic behaviour). These features are fundamental in the study of fault dynamics. Faults or fault zones, in particular, can be important conduits for fluid flow in the lithosphere (e. g., Kerrich, 1986; Caine et al., 1996; McCaig, 1997), and, in this context, hydrothermal mineralization and alteration processes (by possibly CO2-saturated fluids) have a high potential in influencing the rheological response of the crust and the mechanics of faults. In addition to the normal-shear stress and possible fluid overpressure, hydrothermal processes may facilitate the shear failure propagation due to mechanical weakening and dissolution of the wall rock, generating earthquake swarms (Sibson 2000; Heinicke et al., 2009; Chiodini et al., 2020). Some authors suggest that hydrothermal alteration in fluid-filled fracture zones can reduce the friction of asperities and fissures by dissolving crystal edges and/or by argillitization (e.g., Heinicke et al., 2009). Heinicke et al. (2009) propose that friction is not reduced where no alteration processes affect the host-rock, and increased stress must be accumulated before failure of pre-existing ruptures occurs. As a result, fewer earthquakes with higher magnitudes will be generated in the latter case (Heinicke et al., 2009). However, sealing of fractures and pore space in fault rocks after the crystallization of new phases in time periods between seismic events leads to a decrease of permeability and generation of pods of abnormally pressured fluids, which may have a 
fundamental role in the initiation of large earthquakes (Bruhn et al., 1994). It has been observed, however, that both the mineralogical composition of the altered zone and the accumulation of damage and degree of healing are important factors controlling the mechanical properties of a fault (i.e. fault-proximal weakening vs. strengthening) and the mobility of chemical elements along it (Arancibia et al., 2014; Callahan et al., 2019): for instance, strength increases when mineral precipitation reduces microfracture porosity to $<10-15 \%$ of total microfracture area (Faulkner et al., 2008; Holland and Urai, 2010; Callahan et al., 2019).

Mass transfer processes and mineral reactions are enhanced by long term fluid-rock interaction during interseismic periods; mineral reactions gradually modify the composition and texture of fault rocks, controlling their mechanical properties and accommodating aseismic creep (e.g., Sibson, 1977; Wintsch et al., 1995; Collettini et al., 2009; Gratier et al., 2011; Mittempergher et al., 2014). P- and S-wave velocities also decrease in hydrothermally altered fault rock relative to the wall rock (Bruhn et al., 1994).

Several types of mineralizations, with the potential presence of phyllosilicates, can occur along faults according to depth, P-T conditions of formation and chemistry of the circulating fluid. In particular, when present in significant amounts, phyllosilicate minerals influence fault strength by facilitating shear localization in the weak fault rock matrix (Shimamoto and Logan, 1981; Gapais, 1989; Moore and Byerlee, 1989; Blenkinsop and Sibson, 1992; Tembe et al., 2010; Cavailhes et al., 2013; Sánchez-Roa et al., 2017).

Exhumed faults provide measures to investigate the interplay among the aforementioned fault deformation mechanisms, fluid-rock interaction processes and mass redistribution along faults at depth. Here, we provide the microstructural, mineralogical and petrological description of an exhumed hydrothermally altered fault rock inside a monzogranite to granodiorite of the Granite Harbour Intrusives (GHI) from the eastern margin of the Rennick Graben in the Lanterman Range (northern Victoria Land, Antarctica). The multiple $\mathrm{cm}$-thick fault zone is part of a regional ENE-WSW km-scale fault system that transects the Lanterman Range and is characterized by a polyphase deformation history accompanied by multi-stage fluid circulation and periods of inter-slip cementation by hydrous minerals. The persistent fluid-rock interaction during slip along this fault produced cross-cutting calcite-epidote-prehnite-rich ultracataclasite layers, microveins and pseudotachylytes.

The aim of this work is to highlight how the occurrence of epidoteand prehnite-rich hydrothermal alterations can affect the mechanical behaviour of faults, inducing the hardening of the fault rock. We also show that the presence of randomly growing phyllosilicates (i.e. prehnite) apparently does not trigger major phases of slip, but does contribute to the overall strengthening of the fault. The study, furthermore, provides new insights into the deformation mechanisms of epidote and prehnite within a polyphase fluid-assisted tectonic environment.

\section{Geological background}

Northern Victoria Land (nVL) is located at the Pacific end of the Transantarctic Mountains. Its basement results from the juxtaposition of three lithotectonic units during the late Neoproterozoic to early Paleozoic Ross Orogeny (e.g., Bradshaw and Laird, 1983; Weaver et al., 1984; Bradshaw et al., 1985; GANOVEX Team, 1987; Kleinschmidt and Tessensohn, 1987; Stump, 1995; Capponi et al., 1999; Roland et al., 2004; Federico et al., 2006, 2010). These are, from $\mathrm{W}$ to the $\mathrm{E}$, the polymetamorphic and magmatic Wilson Terrane, the central island-arc- or arc/back-arc-related metasedimentary to-volcanic Bowers Terrane, and the external turbidite succession of the Robertson Bay Terrane (e.g., Wright et al., 1984; Borg and Stump, 1987; GANOVEX Team, 1987; Black and Sheraton, 1990; Capponi et al., 1999; Di Vincenzo and Rocchi, 1999; Rocchi et al., 2003, 2011; Roland et al., 2004; Schüssler et al., 2004; Federico et al., 2006; Bracciali et al., 2009; Goodge et al., 2012,
2020; Estrada et al., 2016) (Fig. 1).

The boundaries between these units consist of two major faults or shear zones that are characterized by a polyphase and long-lasting history. The Lanterman Fault separates the Wilson and the Bowers terranes (e.g., Capponi et al., 1999; Rossetti et al., 2002), whereas the Leap Year Fault, as the western termination of the larger Millen Shear Zone, defines the boundary between the Bowers and Robertson Bay terranes (e.g., Crispini et al., 2014; Phillips et al., 2014).

The Lanterman Fault, which is the main subject of this study, is best exposed in the north-eastern Lanterman Range, located on the eastern shoulder of the Rennick Graben (Tessensohn et al., 1981; Rossetti et al., 2003) (Fig. 2). The Lanterman Range mainly consists of high-grade polymetamorphic gneisses and amphibolites of the Wilson Terrane (e. g., Grew and Sandiford, 1984; Roland et al., 1984; Kleinschmidt et al., 1987; GANOVEX Team, 1987), which are intruded by predominantly I-type granitoids (e.g., Borg and Stump, 1987; Borg et al., 1987; Vetter and Tessensohn, 1987; Armienti et al., 1990). The contact between the Wilson Terrane and the Bowers Terrane, in the north-eastern Lanterman Range, is characterized by a tectonic melange that comprises ultra-high-pressure mafic to ultramafic rocks enclosed as bodies and discontinuous layers in gneisses as well as highly deformed low-grade metaconglomerates of mafic to felsic compositions (Gibson, 1984, 1987; Ricci et al., 1996; Capponi et al., 1994, 1997, 1999; Di Vincenzo et al., 1997; Talarico et al., 2004; Palmeri et al., 2011). The different rock slices are separated by a narrow network of anastomosing faults and shear zones of the Lanterman Fault (Capponi et al., 1999; Rossetti et al., 2002). This fault or fault zone, which can be traced from the Pennell coast at the Pacific Ocean along the eastern margin of the Rennick Glacier and the western Bowers Mountains into the Lanterman Range and finds its southern continuation in the Mountaineer Range (Capponi et al., 1999; Rossetti et al., 2002), is interpreted as a major NNW-SSE striking structure that transects both the whole nVL crust and the Cenozoic rift basin of the Ross Sea (Storti et al., 2006).

The kinematics of the Lanterman Fault zone has been long debated, although there is now consensus that it experienced a polyphase ductile to brittle tectonic evolution that likely started at least at ca. $480 \mathrm{Ma}$ during the late Ross Orogeny (Capponi et al., 1999; Rossetti et al., 2002; Crispini et al., 2007). Structural evidence suggests that the Lanterman Fault was first a thrust fault juxtaposing the Wilson Terrane over the Bowers Terrane (e.g., Tessensohn, 1984; Gibson et al., 1984; Capponi et al., 1999). One meter to a few tens of meters thick shear and fault zones indicate subsequent late- and/or post-Ross-age and up to low-grade left-lateral transtensional shearing which caused the transformation of mafic and ultramafic rocks into lenses of chlorite-actinolite schists, mylonite (mostly listvenites) and minor cataclasite (Capponi et al., 1999; Crispini and Capponi, 2002; Ghiribelli et al., 2002; Pour et al., 2019). Finally, Cenozoic (post-50-40 Ma) brittle extensional/transtensional to dextral strike-slip tectonics, as possible response to the onshore prolongation of intra-oceanic facture zones in the Pacific Ocean, affected the whole of nVL and the Ross Sea crust (e.g., Salvini et al., 1997; Rossetti et al., 2006; Storti et al., 2007). This latest episode of tectonism has led to a complex NNW-SSE to NW-SE striking anastomosing dextral fault pattern reactivating inherited anisotropies within the Paleozoic basement and contributing to the formation of the Rennick Graben as a narrow extensional to transtensional basin (Rossetti et al., 2002, 2003). In this model, the northern segment of the Lanterman Fault coincides with the eastern boundary fault of the Rennick Graben, i.e. the Rennick Graben Fault (RGF) in this study (Figs. 1 and 2). Along-strike bending of the whole Lanterman Fault-Rennick Graben Fault system from NNW-SSE directions to NW-SE to E-W directions in the Lanterman Range corresponds to partitioning of strain and progressive transition from strike-slip-related dominant extension and transtension to local dominant transpression in the Lanterman Range, resulting in a km-scale push-up structure and well-expressed anastomosing fault strands in the intra-fault sections (Capponi et al., 1999; Rossetti et al., 2002, 2003; Crispini et al., 2014). Alternative models interpret the opening of the 


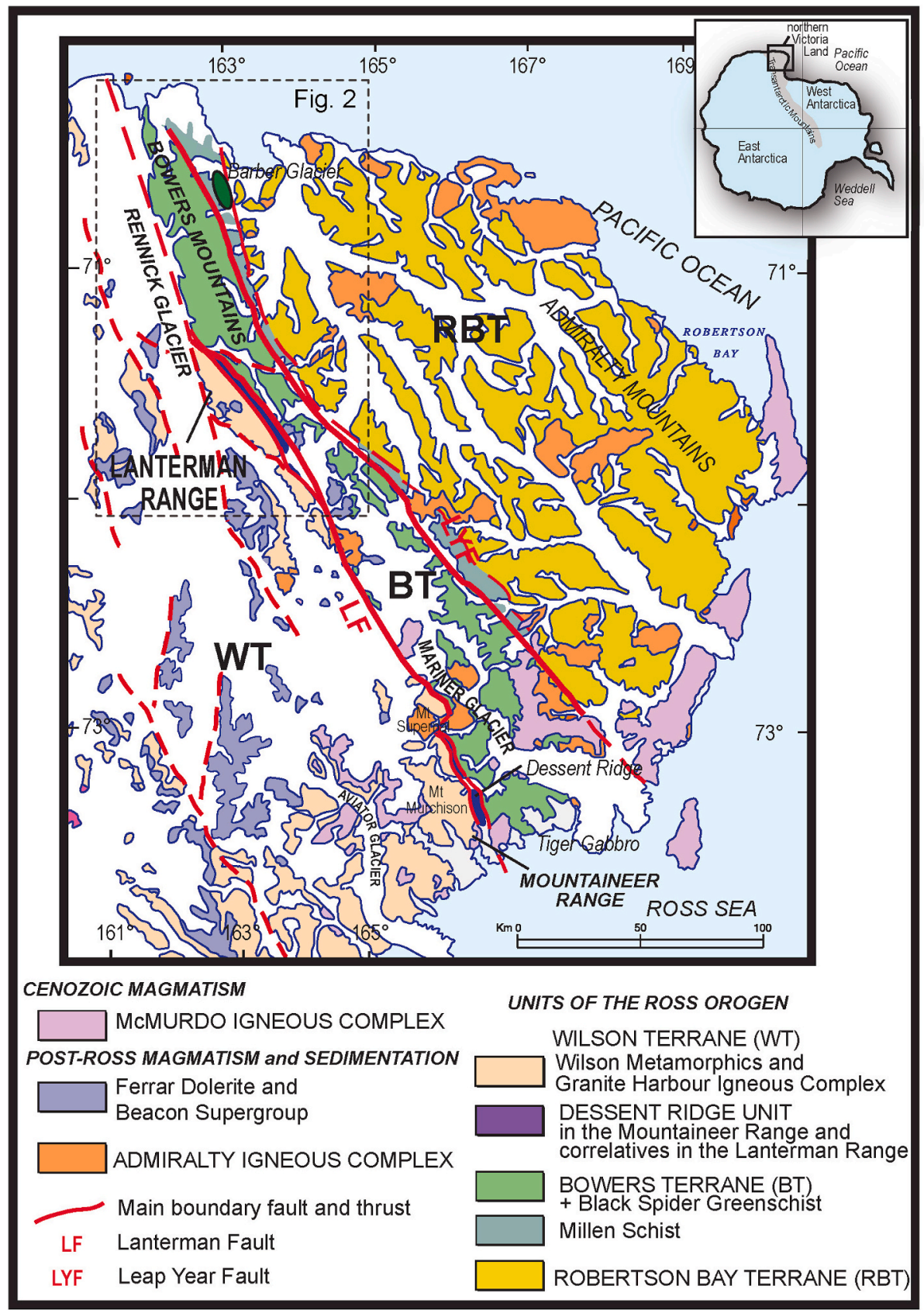

Fig. 1. Schematic geological map of northern Victoria Land (modified after Pertusati et al., 2016). The inset shows the location of northern Victoria Land in Antarctica.

Rennick Graben and the Ross Sea rift basins as pull-aparts linked to Cretaceous NW-SE trending left-lateral strike-slip faulting reactivating inherited structures in nVL (Tessensohn, 1994; Ferraccioli and Bozzo, 2003).

Generally, main fault surfaces dip westward and are associated with cataclasites and fault gouges (Rossetti et al., 2003; Federico et al., 2010). Steeply dipping subsidiary faults in the damage zones show mostly small displacement (some centimetres) along single shear surfaces and larger displacement (ten of metres) in composite fault zones with decimetre-to metre-thick cataclastic cores, which are compatible with sinistral sense of shear (Federico et al., 2010) overprinted by NW-SE directed dextral shear (Rossetti et al., 2003; Storti et al., 2006). Recently, GPS data indicate active left-lateral strike-slip motion in the NNW-SSE segment of the Lanterman Fault in the Lanterman Range (Dubbini et al., 2010).

Both major regional-scale lineaments and intra-terrane fault systems in $\mathrm{nVL}$ are associated with hydrothermal/metasomatic alteration zones, syntectonic mineralizations and deformation zones with ultracataclasites and pseudotachylytes (Crispini and Capponi, 2002; Di Vincenzo et al., 2004, 2013; Federico et al., 2010; Crispini et al., 2011, 2014; Pour et al., 2019). The hydrothermal/metasomatic alterations affect mainly the damage zone of faults and are often associated with diffuse networks of syntectonic polyphase veins. Four main types of alterations can be distinguished (Crispini et al., 2011, 2018; Malatesta et al., 2018a; Pour et al., 2019): (i) foliated listvenites after carbonation processes of mafic and ultramafic rocks along brittle-ductile shear zones; (ii) $\mathrm{Mg}-\mathrm{Ca}-\mathrm{Fe}$ carbonation and/or silicification of metavolcanic rocks associated with syntectonic carbonate coatings on fault planes, hydraulic brecciation, and quartz-carbonate veining; (iii) epidote-bearing slickensides, epidote veining and epidotization in low-grade metabasalts and in amphibolites in the Lanterman Range and the Bowers 

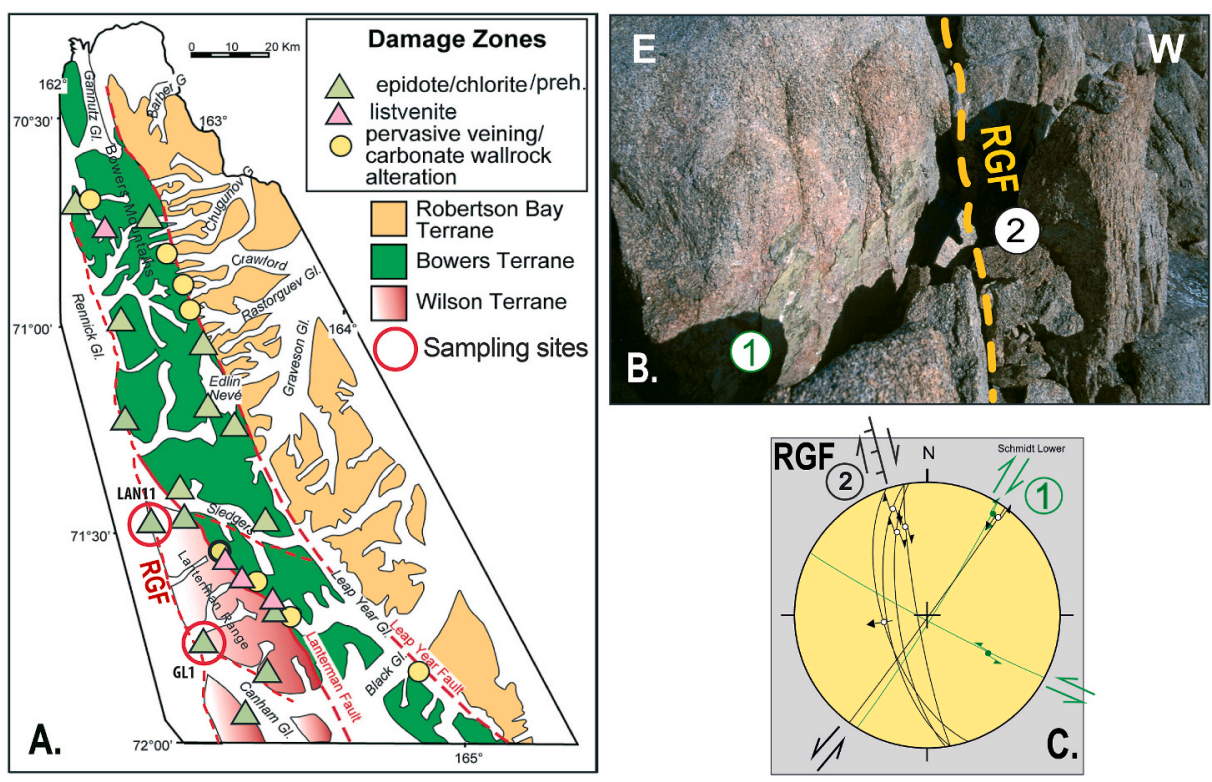

Fig. 2. A) Sketch map with the location of the damage zones where the hydrothermal alteration and veining is more intense (modified after Federico et al., 2010 and Pour et al., 2019). B) Example of a fault zone in granitoids from the north-western side of the Lanterman Range. Note the pink alteration of granite (see text for explanation) and NNE-SSW slickensides with concordant epidote-prehnite fault vein mineralization (labeled 1 in Fig. 2C). RGF: trace of NNW-SSE brittle fault sets oriented parallel to the Rennick Graben and Lanterman Fault and cross-cutting the fault vein (labeled 2 in Fig. 2C); subparallel Riedel shears are compatible with dominant dextral strike-slip along these faults. C) Fault-slip data (planes and striae with slip direction) of (B) are shown as great circles and arrows in lower hemisphere stereographic projections (Win-Tensor software, Delvaux and Sperner, 2003). (For interpretation of the references to color in this figure legend, the reader is referred to the Web version of this article.)

Mountains; (iv) epidote-chlorite-prehnite-bearing cataclastites, ultracataclastites, and indurated gouges in fault cores, with saussuritization of K-feldspar in the wallrock of granitoid rocks.

\section{Material and Methods}

\subsection{Sample collection, preparation and preliminary study}

Structural investigations, collection of data and sampling were accomplished during joint Italian (PNRA) - German (GANOVEX) Scientific Expeditions in Antarctica. Nine rock samples from fault systems transecting the Lanterman Range were prepared to obtain polished thin sections (Fig. 2). The samples were cut normal to the foliation/layering and the fault zone and parallel to the minerals preferred orientation and the strike-slip lineation (i.e. XZ plane, Fig. 3A). Using a polarising optical microscope, we defined the main microstructural, petrographical and mineralogical characteristics of the wall- and the fault-rock. We later selected three representative samples (LAN 11, 281214GL1 and 281214GL1D - hereafter GL1 and GL1D, respectively; Figs. 2A and 3A, $\mathrm{B}, \mathrm{C})$ to further investigate the fault rock characteristics using multiapproach analytical techniques (i.e. EMPA-WDS, XRD and EBSD analyses). Here, we show the results of the two samples LAN 11 and 281214GL1), which we considered to be the most significant and peculiar ones with regard to the key targets of this study.

Micro-chemical analyses were performed taking advantage of an Electron Microprobe (JEOL 8200 Super Probe) at the 'Ardito Desio' Earth Sciences Department (University of Milan, Italy) that used a WDS system; the working conditions were set at $15 \mathrm{kV}$ accelerating voltage
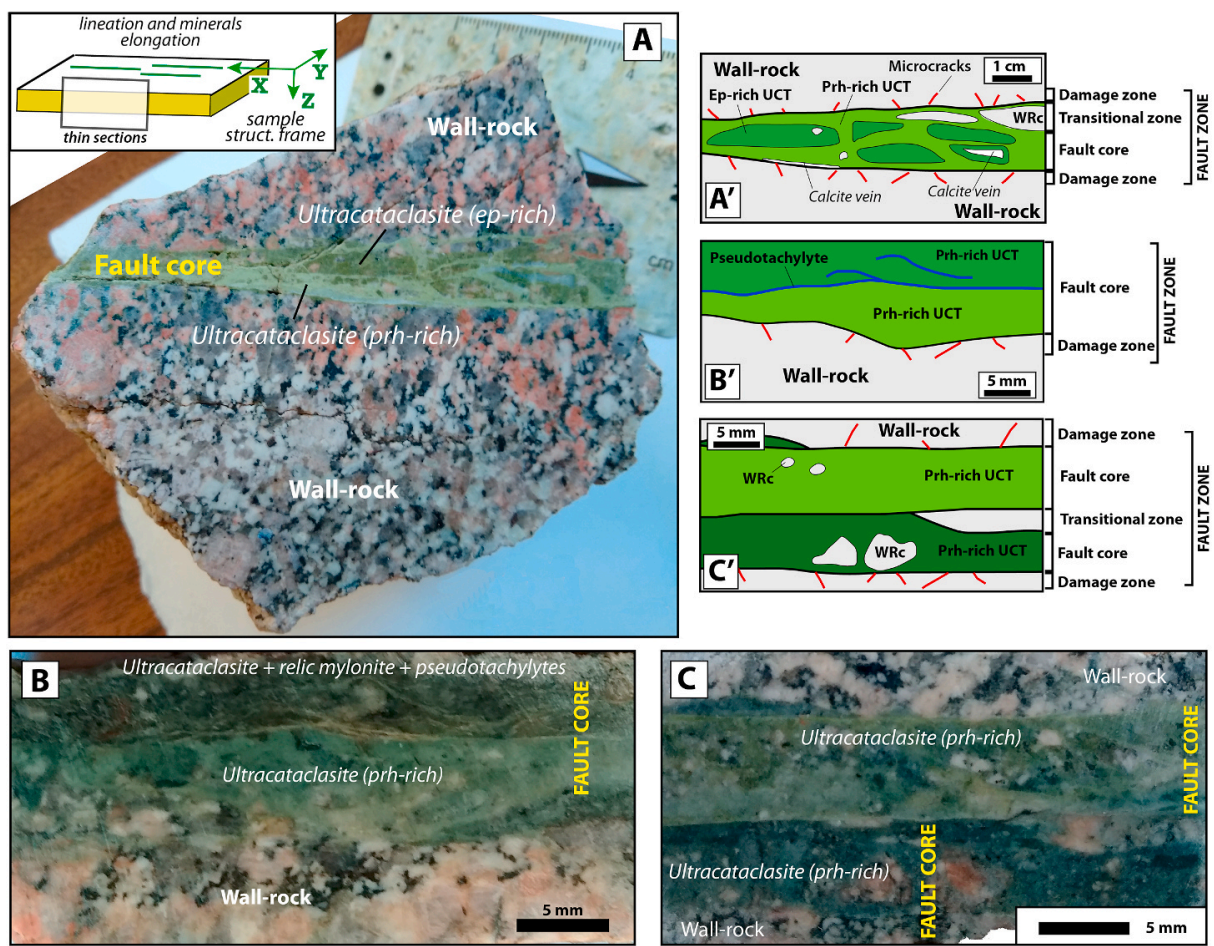

Fig. 3. Structural characteristics of the studied samples: A) LAN 11 hand specimen of and its schematic representation in $A^{\prime}$. The inset shows the structural reference frame used for thin sections preparation. $\mathrm{X}, \mathrm{Y}, \mathrm{Z}$ are the main axes of the strain ellipsoid; B) and $\mathrm{B}^{\prime}$ ) close-up of the polished cut surface of sample 281214GL1 and its simplified representation; $\mathrm{C}$ and $\mathrm{C}^{\prime}$ ) close-up of the polished cut surface of sample 281214GL1D and its simplified representation. In sample LAN 11, both the pink-colored zones and the epidote-rich layers boudinaged inside prehnite-rich UCTs are well visible. The nomenclature for fault rock description is after Caine et al. (1996) and Choi et al. (2016). See text for further explanation of the studied structural zones. (For interpretation of the references to color in this figure legend, the reader is referred to the Web version of this article.) 
and $4.9 \mathrm{nA}$ beam current; natural minerals were used as standards.

Qualitative bulk mineralogical analyses on pulverized fault rock from the samples were done by X-ray diffraction (XRD) using a Philips PW3710 diffractometer, current $20 \mathrm{~mA}$ and voltage $40 \mathrm{kv}$, at the University of Genoa (Italy) as well as a PANalytical X'Pert PRO MDP diffractometer (Co-K $\alpha$ radiation generated at $40 \mathrm{kV}$ and $40 \mathrm{~mA}$ ) at BGR in Hannover (Germany). Table 1 shows the analyses of representative minerals and Supplementary Fig. 1 includes representative XRD patterns of LAN 11 and GL1 samples.

\subsection{EBSD analyses}

Electron backscattered diffraction (EBSD) analysis was carried out using a CamScan X500FE CrystalProbe with an Oxford/HKL EBSD system and the AZtecHKL acquisition software by Oxford Instruments operating at "Géosciences Montpellier" in Montpellier University (France). The operating conditions of the SEM/EBSD were set at $15 \mathrm{kV}$ accelerating voltage, and $3.5 \mathrm{nA}$ beam current. In individual EBSD scans the step size varied between 0,3 and $2 \mu \mathrm{m}$. EBSD data were first processed using the CHANNEL5 software from Oxford Instruments HKL to remove isolated single pixels and to increase the indexation rate by filling automatically the non-indexed pixel having at least 6 neighbours indexed for single phase. The EBSD data were then processed using the MTEX toolbox (version 4.5.2) in MATLABTM [e.g., Hielscher and Schaeben, 2008; Mainprice et al., 2015]. Grains smaller than two pixels were discarded and a $10^{\circ}$ threshold angle between neighbouring pixels was used to automatically identify grain boundaries.

The crystallographic preferred orientation (CPO) and grain misorientation analysis of the main mineral phases (i.e., epidote, prehnite, albite, K-feldspar, quartz, and calcite) in the fault zone were measured on the oriented thin sections, cut parallel to the main slip zone and parallel to mineral lineation (i.e. XZ plane of the strain ellipsoid, Fig. 3A). The misorientation is quantified using the misorientation of each pixel with respect to the mean orientation of pixels within a single grain (mis2mean). Grain Orientation Spread (GOS) values represent the average of mis2mean within a single grain. Deformation is further charaterized by plotting the $2^{\circ}-10^{\circ}$ misorientation rotation axes in the crystallographic reference frame (Inverse Pole Figures). The CPO are displayed as equal area, lower hemisphere projections, representing the Orientation Distribution Function (ODF) using the average orientation of each grain. From the six total areas analyzed in LAN 11 and GL1 samples (i.e., three areas in each sample), we selected one sub-area in LAN 11 and one in GL1 samples, that well represent epidote- and prehnite-rich ultracataclasites (hereafter UCTs) and pseudotachylyte layers, respectively, for EBSD mapping,. Indexation rate ranges between $62 \%$ in pseudotachylyte-layers area to $93 \%$ in the epidote- and prehniterich UCTs areas.

\section{Results}

\subsection{Fault zone structure}

For this study we selected two fault zones, considered as part of the Lanterman Fault-Rennick Graben Fault system, cropping out on the western shoulder of the Lanterman Range (Figs. 1 and 2). They have the same structural features and orientation, i.e. they are multicore mineralized fault zones in granitoid rocks of the GHI (Fig. 2A-C).

The studied samples derive from the northwestern corner of the Lanterman Range at the eastern margin of the Rennick Graben (Fig. 2A). Crosscutting relationships there indicate an older conjugate fault system with coeval fault epidote-prehnite vein mineralization, which is overprinted by brittle NNW-SSE striking extensional and dextral and conjugate sinistral strike-slip faults (e.g.; Fig. 2B and C). These younger faults are most likely related to Cenozoic tectonics along the Lanterman Fault-Rennick Graben Fault system (Rossetti et al., 2002, 2003). The older system may thus be of pre-Cenozoic age.
The host-granitoid rocks affected by the fault zones have a hypidiomorphic texture and consists of pluri-mm-size euhedral to subhedral crystals of prevailing white plagioclase, light-pink K-feldspar and minor grey quartz and black biotite crystals. The fault zones occur in conjugate sets, Riedel shears or splay fault veins with evidence of multiple kinematics. They are about $3-5 \mathrm{~cm}$ thick, show slickensides and are characterized by a strong asymmetry (Fig. 3 ). $\mathrm{A} \approx 1.5 \mathrm{~cm}$-thick fault core has a sharp contact with the host-rock on one side, whereas the other side consists of a $0.5 \mathrm{~cm}$-thick transitional zone; the damage zones affecting the fault wall-rocks on both sides of the fault core are $0.5-1 \mathrm{~cm}$-thick (Fig. 3A-C and $\mathrm{A}^{\prime}-\mathrm{C}^{\prime}$ ). In one sample (GL1D), there are crosscutting cores of two different fault generations, which are separated by a transitional zone (Fig. 3C, $\mathrm{C}^{\prime}$ ). The damage zones are characterized by a dark-pink stain and by microcracks, filled mainly by epidote, which depart from the fault core and affect the first millimeters of the wall-rock; there, macroscopically grey quartz crystals and dark-pink K-feldspar predominate. The transitional zone is characterized by light-green layers of ultracataclasites (about $500 \mu \mathrm{m}$-thick) wrapping $\mathrm{mm}$-to $\mathrm{cm}$-size fragments of the wall-rock (Fig. 3). The fault core consists of different generations of mm-wide (a) dark- and (b) light-green ultracataclasite layers, (c) whitish calcite veins with superposed slip zones. In GL1 sample lightgreen layers (b) prevail over dark-green UCT (a), whereas mm-thick very dark-green layer including UCT, relict mylonite and very dark-green to black-colored layers (d) mark the contact between the fault core and the wall-rock (Fig. 3B, $\mathrm{B}^{\prime}$ ). The dark-green layers (a) are epidote-rich and preserve pluri- $\mu \mathrm{m}$ to $\mathrm{mm}$-size relicts of wall-rock minerals and calcite clasts, the latter deriving from the cataclasis of calcite veins (c); these layers are boudinaged inside light-green layers (b). Light-green layers (b) consist of different generations of UCT (light-to dark-brown at the optical microscope), including tens of $\mu \mathrm{m}$-size clasts of randomly oriented wall-rock minerals in a prehnite-rich matrix. The clasts are subangular with an irregular shape and locally with embayed margins. UCT generations differ mainly in the grain-size of prehnite in the matrix (about $10-80 \mu \mathrm{m}$ in size), which generally decreases in the younger generations. UCT with coarser prehnite are boudinaged and disrupted in UCT with increasingly smaller prehnite crystals, forming mm-size clasts that are locally rotated at high angle compared to the new brittle shear zone (Fig. 4A); prehnite-filled syntaxial veins and vugs that randomly crosscut the UCT. Very dark-green- to black-colored layers (d) appear very cloudy and dark at the optical microscope. They have sharp contacts with UCT layers, cutting both dark-, light-green layers and prehnite veins and producing micro-injection veins in the UCTs (Fig. 4B); layers (d) consist of slightly oriented pluri- $\mu \mathrm{m}$-size irregular clasts of wall-rock and alteration minerals (i.e., K-feldspar, quartz, plagioclase, epidote, allanite and minor calcite, sphene, apatite and zircons) in a matrix of sub- $\mu \mathrm{m}$ to $\mu \mathrm{m}$-size clasts of wall-rock crystals, prehnite and minor chlorite. These layers occur mainly at the contact between the fault core and the wall-rock and are highly asymmetric, focusing on one side of the fault core, where mylonite relicts, fluidal structures and anastomosing surfaces can be observed.

\subsection{Microstructures}

\subsubsection{Wall-rock}

The granitoid rock (monzogranite to granodiorite) has a hypidiomorphic texture consisting of pluri-mm-size euhedral to subhedral crystals of K-feldspar, plagioclase, quartz, biotite and minor zircon, opaque minerals and apatite with $\mu \mathrm{m}$-to pluri- $\mu \mathrm{m}$-size inclusions of quartz plus glass. K-feldspar, plagioclase and biotite (in decreasing order of abundance) prevail in the wall-rock far from the fault core. The magmatic minerals are increasingly altered approaching the fault zone, and K-feldspar, quartz and plagioclase become the predominant phases.

Biotite is fully replaced by pre-kinematic chlorite, white mica, sphene and locally by prehnite (Figs. 4C and 5A). Dark pink crystals consist of K-feldspar, which is pseudomorphically replaced by Na-rich plagioclase (albite), and are particularly abundant close to the fault 
Table 1

Electron microprobe analyses of representative minerals from the wall rock and the fault zone.

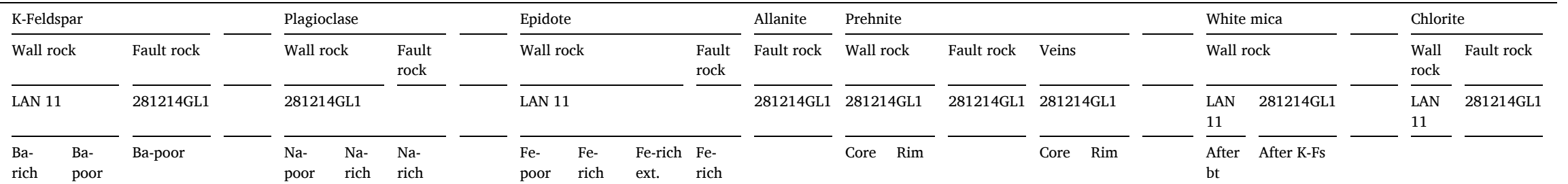

$\begin{array}{llllll}\text { rich poor poor rich rich } & \text { poor rich ext. rich } \\ & & \text { core core core core }\end{array}$ $\begin{array}{llll}\text { core } & \text { core } & \text { Core } & \text { core } \\ (1) & (2) & (2) & (2)\end{array}$

\begin{tabular}{llll}
\hline $\mathrm{SiO} 2$ & 65.86 & 67.09 & 66.09 \\
$\mathrm{TiO} 2$ & 0.01 & 0.00 & 0.05 \\
$\mathrm{Al} 2 \mathrm{O} 3$ & 18.69 & 18.58 & 18.03 \\
$\mathrm{Cr} 2 \mathrm{O} 3$ & 0.00 & 0.00 & 0.05 \\
$\mathrm{FeO}$ & 0.00 & 0.00 & 0.25 \\
$\mathrm{MgO}$ & 0.02 & 0.00 & 0.01 \\
$\mathrm{MnO}$ & 0.06 & 0.00 & 0.04 \\
$\mathrm{CaO}$ & 0.09 & 0.02 & 0.12 \\
$\mathrm{Na} 2 \mathrm{O}$ & 1.35 & 0.12 & 0.10 \\
$\mathrm{~K} 20$ & 14.21 & 15.81 & 15.80 \\
$\mathrm{Sum}$ & 100.28 & 101.63 & 100.56 \\
$\mathrm{Pr} 2 \mathrm{O} 3$ & 0.00 & 0.00 & 0.02 \\
$\mathrm{Nd} 2 \mathrm{O} 3$ & 0.01 & 0.00 & 0.04 \\
$\mathrm{Rb} O$ & 0.00 & 0.00 & 0.00 \\
$\mathrm{~L} 2 \mathrm{O} 3$ & 0.00 & 0.04 & 0.02 \\
$\mathrm{Cs} 2 \mathrm{O}$ & 0.00 & 0.04 & 0.01 \\
$\mathrm{Ce} 2 \mathrm{O} 3$ & 0.20 & 0.08 & 0.00 \\
$\mathrm{BaO}$ & 0.53 & 0.00 & 0.04 \\
$\mathrm{Sum}$ & 101.02 & 101.79 & 100.69 \\
$\mathrm{Si}$ & 3.01 & 3.03 & 3.03 \\
$\mathrm{Ti}$ & 0.00 & 0.00 & 0.00 \\
$\mathrm{Al}$ & 1.01 & 0.99 & 0.97 \\
$\mathrm{Cr}$ & 0.00 & 0.00 & 0.00 \\
$\mathrm{Fe}$ & 0.00 & 0.00 & 0.01 \\
$\mathrm{Mg}$ & 0.00 & 0.00 & 0.00 \\
$\mathrm{Mn}$ & 0.00 & 0.00 & 0.00 \\
$\mathrm{Ca}$ & 0.00 & 0.00 & 0.01 \\
$\mathrm{Na}$ & 0.12 & 0.01 & 0.01 \\
$\mathrm{~K}$ & 0.83 & 0.91 & 0.92 \\
$\mathrm{~V}$ & 0.00 & 0.00 & 0.00 \\
$\mathrm{Sum}$ & 4.97 & 4.94 & 4.95
\end{tabular}

\begin{tabular}{|c|c|c|c|c|c|c|c|c|c|}
\hline & 59.28 & 67.30 & 70.15 & $\mathrm{SiO} 2$ & 38.35 & 38.20 & 37.87 & 38.10 & 33.65 \\
\hline $\mathrm{TiO} 2$ & 0.04 & 0.01 & 0.00 & TiO2 & 0.00 & 0.11 & 0.05 & 0.09 & 0.76 \\
\hline $\mathrm{Al} 2 \mathrm{O} 3$ & 24.13 & 19.92 & 20.07 & $\mathrm{Al} 2 \mathrm{O} 3$ & 25.55 & 23.17 & 22.33 & 21.18 & 14.77 \\
\hline $\mathrm{Cr} 2 \mathrm{O} 3$ & 0.02 & 0.00 & 0.00 & $\mathrm{Cr} 2 \mathrm{O} 3$ & 0.00 & 0.05 & 0.00 & 0.00 & 0.00 \\
\hline $\mathrm{FeO}$ & 0.08 & 0.00 & 0.14 & $\mathrm{FeO}$ & 9.79 & 12.11 & 13.14 & 14.42 & 15.87 \\
\hline $\mathrm{MgO}$ & 0.00 & 0.00 & 0.01 & $\mathrm{MgO}$ & 0.02 & 0.04 & 0.00 & 0.00 & 0.09 \\
\hline $\mathrm{MnO}$ & 0.00 & 0.00 & 0.06 & MnO & 0.40 & 0.46 & 0.26 & 0.08 & 0.25 \\
\hline $\mathrm{CaO}$ & 5.88 & 0.22 & 0.31 & $\mathrm{CaO}$ & 22.42 & 22.37 & 22.54 & 22.57 & 13.11 \\
\hline $\mathrm{Na} 2 \mathrm{O}$ & 8.02 & 11.67 & 11.11 & $\mathrm{Na} 2 \mathrm{O}$ & 0.00 & 0.01 & 0.01 & 0.03 & 0.00 \\
\hline K20 & 0.20 & 0.10 & 0.14 & K20 & 0.00 & 0.00 & 0.01 & 0.01 & 0.01 \\
\hline Sum & 97.66 & 99.22 & 101.99 & Sum & 96.54 & 96.53 & 96.21 & 96.48 & 78.51 \\
\hline Pr2O3 & 0.00 & 0.00 & 0.00 & Pr2O3 & 0.00 & 0.00 & 0.00 & 0.00 & 0.64 \\
\hline $\mathrm{Nd} 2 \mathrm{O} 3$ & 0.00 & 0.00 & 0.00 & $\mathrm{Nd} 2 \mathrm{O} 3$ & 0.00 & 0.00 & 0.14 & 0.02 & 3.07 \\
\hline $\mathrm{Rb} 2 \mathrm{O}$ & 0.039 & 0.05 & 0.00 & $\mathrm{Rb} 2 \mathrm{O}$ & 0.00 & 0.00 & 0.00 & 0.00 & 0.00 \\
\hline La2O3 & 0.0368 & 0.07 & 0.05 & $\mathrm{La} 2 \mathrm{O} 3$ & 0.00 & 0.00 & 0.00 & 0.00 & 4.91 \\
\hline Cs2O & 0.0489 & 0.11 & 0.05 & $\mathrm{Cs} 2 \mathrm{O}$ & 0.00 & 0.00 & 0.00 & 0.00 & 9.43 \\
\hline $\mathrm{Ce} 2 \mathrm{O} 3$ & 0.00 & 0.03 & 0.00 & $\mathrm{Ce} 2 \mathrm{O} 3$ & 0.00 & 0.00 & 0.02 & 0.00 & 0.08 \\
\hline $\mathrm{BaO}$ & 0.0249 & 0.04 & 0.00 & $\mathrm{BaO}$ & 0.02 & 0.04 & 0.01 & 0.00 & 0.00 \\
\hline Sum & 97.81 & 99.51 & 102.09 & Sum & 96.56 & 96.58 & 96.39 & 96.50 & 96.64 \\
\hline $\mathrm{Si}$ & 2.70 & 2.97 & 3.00 & $\mathrm{Si}$ & 3.05 & 3.07 & 3.06 & 3.09 & 3.32 \\
\hline $\mathrm{Ti}$ & 0.00 & 0.00 & 0.00 & $\mathrm{Ti}$ & 0.00 & 0.01 & 0.00 & 0.01 & 0.06 \\
\hline $\mathrm{Al}$ & 1.30 & 1.04 & 1.01 & $\mathrm{Al}$ & 2.39 & 2.19 & 2.13 & 2.02 & 1.72 \\
\hline $\mathrm{Cr}$ & 0.00 & 0.00 & 0.00 & $\mathrm{Cr}$ & 0.00 & 0.00 & 0.00 & 0.00 & 0.00 \\
\hline $\mathrm{Fe}$ & 0.00 & 0.00 & 0.01 & $\mathrm{Fe}$ & 0.59 & 0.73 & 0.80 & 0.88 & 1.18 \\
\hline $\mathrm{Mg}$ & 0.00 & 0.00 & 0.00 & $\mathrm{Mg}$ & 0.00 & 0.01 & 0.00 & 0.00 & 0.01 \\
\hline Mn & 0.00 & 0.00 & 0.00 & Mn & 0.03 & 0.03 & 0.02 & 0.01 & 0.02 \\
\hline $\mathrm{Ca}$ & 0.29 & 0.01 & 0.01 & $\mathrm{Ca}$ & 1.91 & 1.92 & 1.95 & 1.96 & 1.38 \\
\hline $\mathrm{Na}$ & 0.71 & 1.00 & 0.92 & $\mathrm{Na}$ & 0.00 & 0.00 & 0.00 & 0.00 & 0.00 \\
\hline . & 0.01 & 0.01 & 0.01 & $\mathrm{~K}$ & 0.00 & 0.00 & 0.00 & 0.00 & 0.00 \\
\hline $\mathrm{V}$ & 0.00 & 0.00 & 0.00 & $\mathrm{~V}$ & 0.00 & 0.00 & 0.00 & 0.00 & 0.00 \\
\hline Sum & 5.01 & 5.02 & 4.96 & Sum & 7.96 & 7.96 & 7.97 & 7.96 & 7.68 \\
\hline & & & & & & & & & \\
\hline
\end{tabular}

$\begin{array}{lll}42.06 & 43.29 & 43.90\end{array}$ $\begin{array}{lll}17.10 & 22.85 & 22.47\end{array}$ $\begin{array}{lll}17.10 & 22.85 & 22.47 \\ 0.00 & 0.00 & 0.00\end{array}$ $\begin{array}{llll}0.00 & 0.00 & 0.00 \\ 9.58 & 2.69 & 2.47\end{array}$ $\begin{array}{lll}9.58 & 2.69 & 2.47 \\ 0.00 & 0.04 & 0.04\end{array}$ $\begin{array}{lll}0.00 & 0.04 & 0.04 \\ 0.03 & 0.00 & 0.09\end{array}$ $\begin{array}{lll}0.03 & 0.00 & 0.09 \\ 25.81 & 26.90 & 25.97\end{array}$ $\begin{array}{llll}25.81 & 26.90 & 25.97 \\ 0.09 & 0.02 & 0.03\end{array}$ $\begin{array}{lll}0.09 & 0.02 & 0.03 \\ 0.00 & 0.00 & 0.00\end{array}$ $\begin{array}{lll}0.00 & 0.00 & 0.00\end{array}$ $94.79 \quad 95.86 \quad 95.14$ n.d. n.d. 0.00 n.d. n.d. 0.05 n.d. n.d. 0.00 n.d. n.d. 0.08 n.d. n.d. 0.02 n.d. n.d. 0.00 n.d. n.d. 0.00 $\begin{array}{lll}3.02 & 2.99 & 3.05\end{array}$ $\begin{array}{lll}3.02 & 2.99 & 3.05 \\ 0.01 & 0.00 & 0.01\end{array}$ $\begin{array}{lll}0.01 & 0.00 & 0.01 \\ 1.45 & 1.86 & 1.84\end{array}$ $\begin{array}{lll}1.45 & 1.86 & 1.84 \\ 0.00 & 0.00 & 0.00\end{array}$ $\begin{array}{lll}0.00 & 0.00 & 0.00 \\ 0.52 & 0.14 & 0.13\end{array}$ $\begin{array}{lll}0.52 & 0.14 & 0.13 \\ 0.00 & 0.00 & 0.00\end{array}$ $\begin{array}{llll}0.00 & 0.00 & 0.00\end{array}$ $\begin{array}{lll}0.00 & 0.00 & 0.01 \\ 1.99 & 1.99 & 1.93\end{array}$ $\begin{array}{lll}1.99 & 1.99 & 1.93 \\ 0.01 & 0.00 & 0.00\end{array}$ $\begin{array}{lll}0.01 & 0.00 & 0.00\end{array}$ $\begin{array}{lll}0.00 & 0.00 & 0.00\end{array}$ $\begin{array}{lll}0.00 & 0.00 & 0.00 \\ 7.00 & 7.00 & 6.96\end{array}$ $\begin{array}{lll}7.00 & 7.00 & 6.96\end{array}$

$\begin{array}{llllllll}42.52 & 42.97 & \mathrm{SiO} 2 & 47.21 & 45.39 & \mathrm{SiO} 2 & 29.45 & 29.26 \\ 0.00 & 0.00 & \mathrm{TiO} 2 & 0.39 & 0.01 & \mathrm{TiO} 2 & 0.03 & 0.77 \\ 19.53 & 22.51 & \mathrm{Al} 2 \mathrm{O} 3 & 28.51 & 39.60 & \mathrm{Al} 2 \mathrm{O} 3 & 17.23 & 16.59 \\ 0.00 & 0.05 & \mathrm{Cr} 2 \mathrm{O} 3 & 0.00 & 0.00 & \mathrm{Cr} 2 \mathrm{O} 3 & 0.02 & 0.03 \\ 6.25 & 3.02 & \mathrm{FeO} & 6.30 & 0.51 & \mathrm{FeO} & 24.84 & 27.52 \\ 0.02 & 0.01 & \mathrm{MgO} & 2.48 & 0.00 & \mathrm{MgO} & 16.30 & 13.20 \\ 0.04 & 0.00 & \mathrm{MnO} & 0.04 & 0.00 & \mathrm{MnO} & 0.46 & 0.49 \\ 26.54 & 26.67 & \mathrm{CaO} & 0.12 & 0.00 & \mathrm{CaO} & 0.16 & 0.09 \\ 0.01 & 0.04 & \mathrm{Na} 2 \mathrm{O} & 0.19 & 0.23 & \mathrm{Na} 2 \mathrm{O} & 0.02 & 0.02 \\ 0.01 & 0.00 & \mathrm{~K} 20 & 10.28 & 10.37 & \mathrm{~K} 20 & 0.04 & 0.48 \\ 94.92 & 95.27 & \mathrm{Sum} & 95.52 & 96.12 & \mathrm{Sum} & 88.55 & 88.45 \\ \text { n.d. } & \text { n.d. } & \mathrm{Pr} 2 \mathrm{O} 3 & 0.00 & 0.02 & \mathrm{Pr} 2 \mathrm{O} 3 & 0.00 & 0.06 \\ \text { n.d. } & \text { n.d. } & \mathrm{Nd} 2 \mathrm{O} 3 & 0.01 & 0.08 & \mathrm{Nd} 2 \mathrm{O} 3 & 0.03 & 0.00 \\ \text { n.d. } & \text { n.d. } & \mathrm{Rb} 2 \mathrm{O} & 0.00 & 0.06 & \mathrm{Rb} 2 \mathrm{O} & 0.00 & 0.00 \\ \text { n.d. } & \text { n.d. } & \mathrm{La} 2 \mathrm{O} 3 & 0.00 & 0.00 & \mathrm{La} 2 \mathrm{O} 3 & 0.00 & 0.06 \\ \text { n.d. } & \text { n.d. } & \mathrm{Cs2O} & 0.00 & 0.03 & \mathrm{Cs} 2 \mathrm{O} & 0.05 & 0.00 \\ \text { n.d. } & \text { n.d. } & \mathrm{Ce} 2 \mathrm{O} 3 & 0.15 & 0.06 & \mathrm{Ce} 2 \mathrm{O} 3 & 0.00 & 0.00 \\ \text { n.d. } & \text { n.d. } & \mathrm{BaO} & 0.19 & 0.09 & \mathrm{BaO} & 0.00 & 0.00 \\ 94.92 & 95.27 & \mathrm{Sum} & 95.87 & 96.47 & \mathrm{Sum} & 88.63 & 88.57 \\ 3.02 & 2.99 & \mathrm{Si} & 6.37 & 5.94 & \mathrm{Si} & 6.10 & 6.18 \\ 0.00 & 0.00 & \mathrm{Ti} & 0.04 & 0.00 & \mathrm{Ti} & 0.00 & 0.12 \\ 1.63 & 1.85 & \mathrm{Al} & 4.53 & 6.10 & \mathrm{Al} & 4.21 & 4.13 \\ 0.00 & 0.00 & \mathrm{Cr} & 0.00 & 0.00 & \mathrm{Cr} & 0.00 & 0.00 \\ 0.33 & 0.16 & \mathrm{Fe} & 0.64 & 0.05 & \mathrm{Fe} & 4.31 & 4.86 \\ 0.00 & 0.00 & \mathrm{Mg} & 0.50 & 0.00 & \mathrm{Mg} & 5.04 & 4.16 \\ 0.00 & 0.00 & \mathrm{Mn} & 0.01 & 0.00 & \mathrm{Mn} & 0.08 & 0.09 \\ 2.02 & 1.99 & \mathrm{Ca} & 0.02 & 0.00 & \mathrm{Ca} & 0.04 & 0.02 \\ 0.00 & 0.00 & \mathrm{Na} & 0.05 & 0.06 & \mathrm{Na} & 0.01 & 0.01 \\ 0.00 & 0.00 & \mathrm{~K} & 1.77 & 1.73 & \mathrm{~K} & 0.01 & 0.13 \\ 0.00 & 0.00 & \mathrm{~V} & 0.00 & 0.00 & \mathrm{~V} & 0.00 & 0.00 \\ 7.00 & 7.00 & \mathrm{Sum} & 13.93 & 13.88 & \mathrm{Sum} & 19.80 & 19.70 \\ & & \mathrm{Mg}+ & 1.14 & 0.05 & \mathrm{XFe} & 0.46 & 0.54 \\ & & \mathrm{Fetot} & & & & & \end{array}$

Fetot

n.d. $=$ not determined.

$\begin{array}{lllll}\text { Xcz } & 40.15 & 20.82 & 13.90 & 2.41\end{array}$

$\mathrm{XNa}=\mathrm{Na} /(\mathrm{Na}+\mathrm{Ca}) \mathrm{Xep}=(\mathrm{Fe} /(\mathrm{Fe}+(\mathrm{Al}(\mathrm{VI})-2))) * 100$

$\mathrm{Xczo}=(\mathrm{Al}(\mathrm{VI})-2 /(\mathrm{Al}(\mathrm{VI})-2+\mathrm{Fe}) * 100$.

$\mathrm{XFe}=\mathrm{Fe} /(\mathrm{Fe}+\mathrm{Mg})$. 

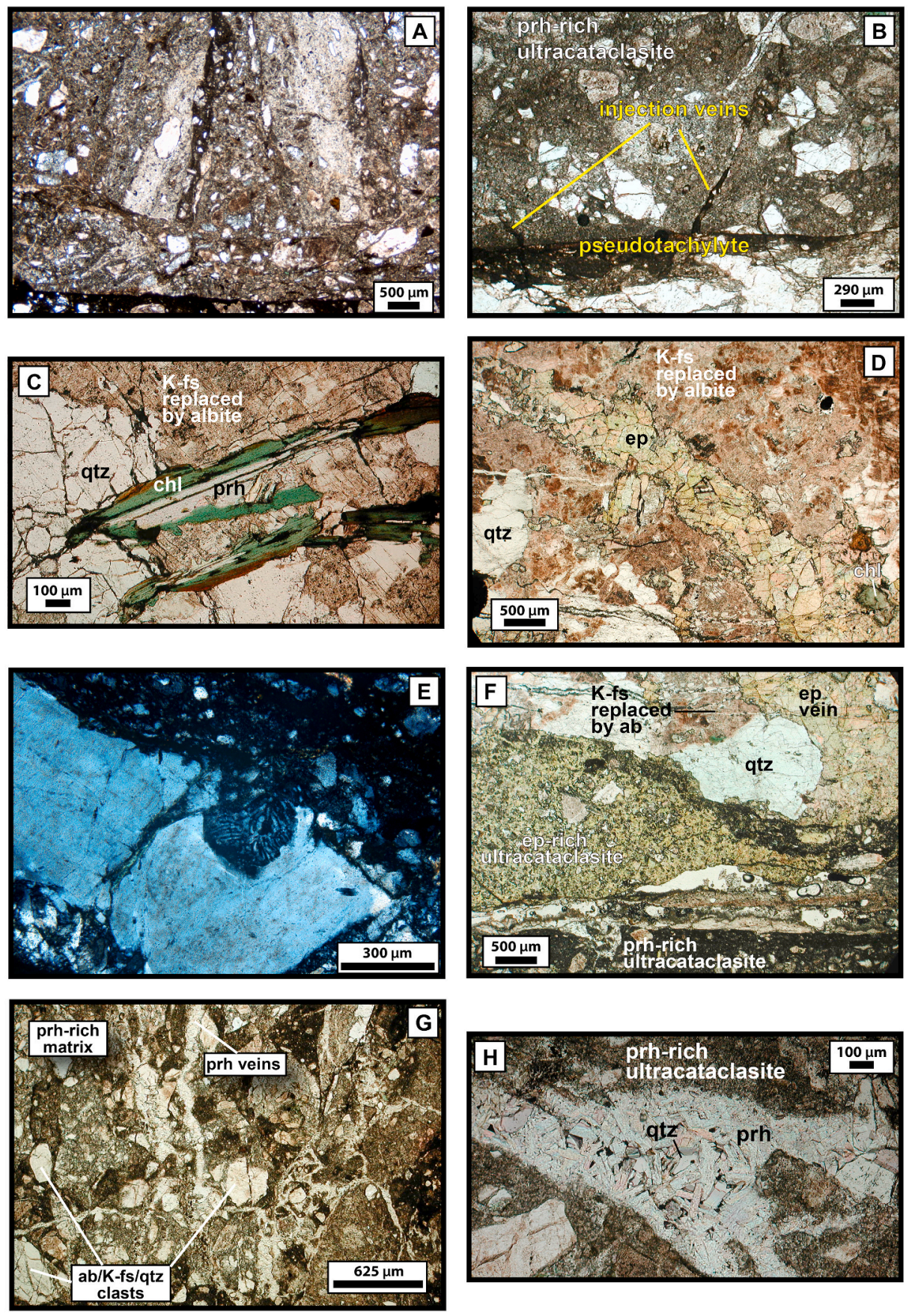

Fig. 4. Photomicrographs of the main representative minerals both in the wall- and in the fault rock. A) Rotated clast in prh-rich UCTs, preserving layers of older prh-rich UCTs (parallel polarized nicols). B) Injection veins departing from the pseudotachylyte layer and crosscutting the prh-rich UCTs (parallel polarized nicols). C) Chl and prh after bt, replacing albitized K-fs. K-fs is pervasively replaced by ab (parallel polarized nicols). D) Ep + chl microvein cutting the damage zone (parallel polarized nicols). E) Myrmekite in a K-fs clast wrapped by pseudotachylytes (crossed polarized nicols). F) Relationship between ep- and prh-rich UCT layers in the fault core, and ep-rich vein in the damage zone (parallel polarized nicols). G) Insight of prh-rich UCTs crosscut by prh-bearing veins. Various generations of UCTs, with variably sized prh crystals matrix, and wall-rock clasts are visible (parallel polarized nicols). H) Vein of prh + qtz cutting prhrich UCT (parallel polarized nicols). Mineral abbreviations are after Kretz (1983). zone; there, K-feldspar occurs only as relicts inside Na-rich plagioclase and is locally overgrown by white mica, chlorite, prehnite, epidote and sphene (i.e., saussuritization). Calcic plagioclase is almost completely replaced by Na-rich plagioclase (i.e., albitization).

\subsubsection{Damage and transitional zones}

In the damage and transitional zones, the alteration of primary minerals and the content of epidote and prehnite replacing them increase proportionally to the proximity to the fault core.

The damage zones are characterized by (i) ductile to brittle-ductile $\mu \mathrm{m}$-thick shear zones and (ii) microveins and microcracks. Both cut the host granitoid rock and are oriented mostly subparallel to or departing from the fault core. The following features were observed in particular: (i) Ductile to brittle-ductile deformation is testified by undulatory extinction of quartz, flame-microperthites in K-feldspar, microshear zones in albitized K-feldspar, and kinked chlorite crystals; quartz shows subgrains, irregular grain boundaries with bulges and aggregates of pluri- $\mu \mathrm{m}$-size new grains.

(ii) Microfractures, locally including about a hundred $\mu \mathrm{m}$-size syn-to post-kinematic prehnite or epidote, crosscut the primary minerals; K-feldspars show microveins (50 $\mu$ m-thick) of synkinematic prehnite + sphene or epidote. Both calcic plagioclase and K-feldspars are crosscut by syntaxial $\mu \mathrm{m}$-thick veins including cross-prismatic crystals of Na-rich plagioclase. Quartz is highly fractured and preserves abundant fluid inclusions trails, mostly subparallel to the fault zone. Thicker ( $500 \mu \mathrm{m}$-thick) microveins, propagating from the fault core and crosscutting primary 

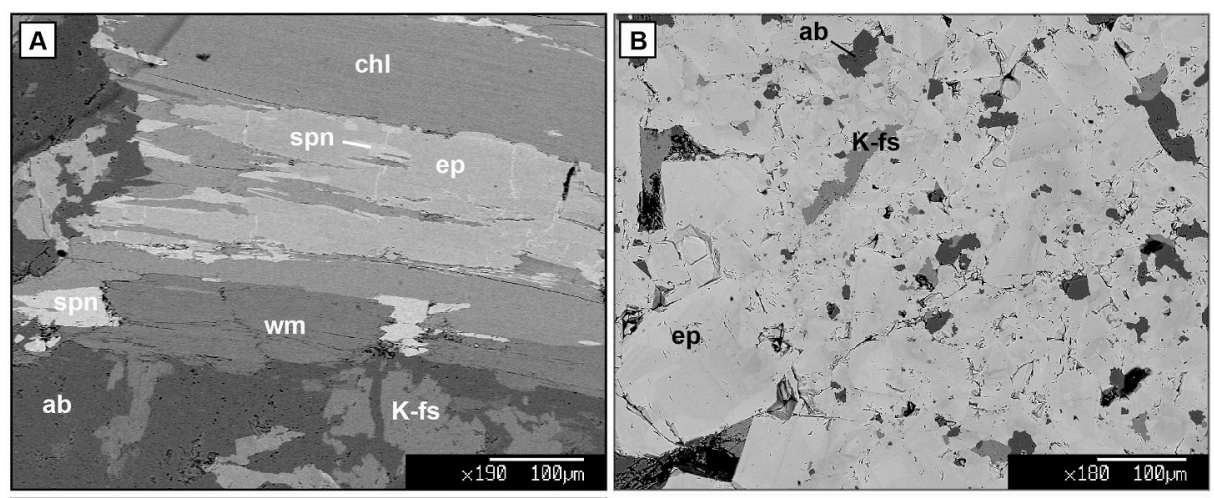

Fig. 5. Electron back-scattered images of the main minerals in the altered fault zone. A) Chl + ep + wm + spn overgrowing albitized K-fs. B) Ep-rich UCT; compositionally zoned ep replaces clasts of wall-rock minerals (e.g. K-fs, ab). C) Prh-rich UCT including clasts of cal and ep and of wall-rock minerals. D) Insight of prh-rich UCT with tens of $\mu \mathrm{m}$-size randomly oriented prh crystals replacing $\mathrm{K}$ fs, qtz and ep clasts. E) Prh + ep vein cutting prhrich UCTs; prh crystals show compositional variations from the core to the rim. F) Insight of pseudotachylyte layer made by $10 \mu \mathrm{m}$-size prevailing $\mathrm{K}$ fs and ab clasts in a matrix of sub- $\mu \mathrm{m}$ to $\mu \mathrm{m}$-size grains of wall-rock-forming minerals and prehnite crystals.
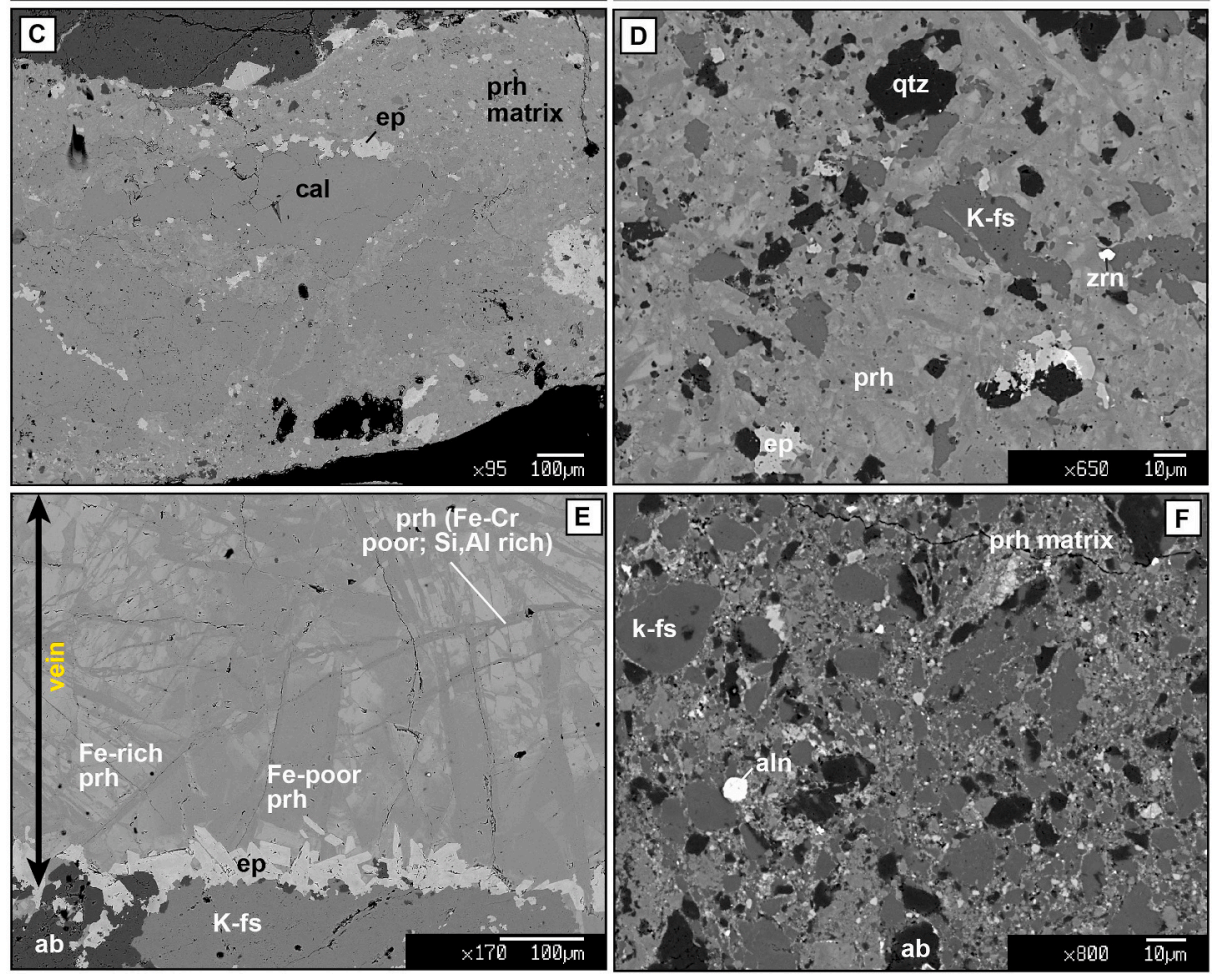

minerals, include euhedral to subhedral $100 \mu \mathrm{m}$-size epidote grains plus sphene and locally chlorite (Fig. 4D).

The deformed areas observed in the damage zone occur also in the transitional zone. There, myrmekite textures are abundant both in albitized K-feldspar crystals and grains (Fig. 4E).

The UCT layers in the transitional zone contain clasts of Na-rich plagioclase, K-feldspar, apatite and allanite; chlorite, epidote, prehnite and quartz of the matrix replace the above phases. Sphene and apatite in mm-size synkinematically grew along $\mu$ m-thick layers marking the contact between the UCT and the wall-rock.

\subsubsection{Fault core}

Dark-green UCT (a) consist of $10 \mu \mathrm{m}$-to $100 \mu \mathrm{m}$-size euhedral to subhedral pre-to syn-kinematic epidote that replaces subordered relicts of randomly oriented wall-rock minerals such as plagioclase, K-feldspar (replaced by Na-rich plagioclase), quartz and calcite (Figs. 4F and 5B).

UCTs in the light-green layers (b) wrap around dark-green layers and consist of:

- mm-size mylonite domains including plastically deformed $\mathrm{K}$ feldspar;
- tens of $\mu \mathrm{m}$-size clasts both of the wall-rock/damage zone (i.e., Kfeldspar, Na-rich plagioclase, quartz), and of epidote-rich layers and calcite (Fig. 5C);

- minor apatite, sphene and $\mu \mathrm{m}$-size zircons.

All these elements are surrounded by a matrix consisting of randomly oriented post-kinematic prehnite + minor chlorite; prehnite replaces all the clasts of the wall-rock/damage zone (Figs. 4G and 5D). All generations of UCTs are matrix-supported and differ only in the size of prehnite (10-80 $\mu \mathrm{m}$-size).

Syntaxial veins and vugs crosscutting the UCTs are filled either by $100 \mu \mathrm{m}$-size euhedral prehnite + minor quartz (Fig. $4 \mathrm{H}$ ), or by $100 \mu \mathrm{m}$ size euhedral prehnite and minor tens of $\mu \mathrm{m}$-size euhedral epidote, the last growing from the walls of the veins/vugs (Fig. 5E). Sub-mm-thick calcite veins (c), from syn-to post-prehnite veins, affect the fault core.

Very dark-green to black-colored layers (d), interpreted here as altered fossil pseudotachylytes (e.g.; Fondriest et al., 2020) or pseudotachylytes of crushing origin, sharply transect UCTs. Pseudotachylytes of crushing origin, which consist of ultracataclastic material and resemble in appearance those formed by friction melting during seismic events, can be generated by crushing and rapid injection accompanied by fluidization of the fine-grained material during seismic faulting, with little or no evidence of melting (e.g., Lin, 2011). 
The pseudotachylytes layers consist of $\mu \mathrm{m}$-to pluri- $\mu \mathrm{m}$-size embayed clasts of wall-rock minerals (i.e., K-feldspar, quartz, plagioclase, epidote, allanite and minor calcite, sphene, apatite and zircons) in a matrix of sub- $\mu \mathrm{m}$ to $\mu \mathrm{m}$-size clasts of wall-rock, sub- $\mu \mathrm{m}$ size prehnite and minor chlorite crystals (Fig. 5F). Compared to the UCT layers, prehnite in the matrix is subordered and tiny clasts of wall-rock minerals prevail. Layers (d) wrap around domains of relict mylonite forming fluidal structures; there, mylonite domains consist of mm-size sigmoidal clasts including deformed K-feldspar with pressure shadows of recrystallized Na-rich plagioclase and white mica, chlorite, apatite, zircons (Fig. 6A-B).

\subsection{Mineral chemistry}

\subsubsection{K-feldspar}

K-feldspar, occurring either in the wall-rock or in the fault zone, can be chemically classified as orthoclase/microcline (Fig. 7). Together with plagioclase, it is one of the main constituents of the wall-rock, damage and transitional zones, and it can be observed as clasts in the UCTs and in pseudotachylyte layers. No significant chemical variations occur between K-feldspar in the wall-rock or in the UCTs. K-feldspar is generally replaced by Na-rich plagioclase, chlorite, white mica, and prehnite. Kfeldspar is either: (A) Ba-rich $(<0.53 \mathrm{wt} \%)$ when pervasevely replaced by Na-rich plagioclase with a composition from $\mathrm{X}_{\mathrm{Na}}=71$ to $\mathrm{X}_{\mathrm{Na}}=99$ (photo GL1c2-2); (B) Ba-poor with scarce exsolutions of Na-rich plagioclase generally starting from the core of the crystal. Both Ba-rich and Ba-poor K-feldspar are present as clasts in the UCTs.

The pinkish color of the crystals, visible at the macro-scale, is related to the abundance of Na-rich plagioclase exsolution (microperthite).

\subsubsection{Plagioclase}

Plagioclase is one of the main components of the wall-rock, damage and transitional zones, occurs as clasts in the UCTs or as recrystallized crystals in the pressure shadows of K-feldspar in relict mylonite wrapped by pseudotachylytes.

Primary Ca-rich plagioclase $\left(\mathrm{X}_{\mathrm{Na}}=\mathrm{Na} /(\mathrm{Na}+\mathrm{Ca})=71\right)$ is almost completely pseudomorphically replaced either by albite (i.e. albitized plagioclase) or K-feldspar, locally resulting in a chessboard-like texture; relict Ca-rich plagioclase is only present in the wall-rock.

The majority of plagioclase both in the wall-rock and in the fault zone has an almost pure albitic composition $\left(\mathrm{X}_{\mathrm{Na}}=99\right)$ (Fig. 7), with about $0.1 \mathrm{wt} \%$ Ce preserved in the core. There are no significant chemical variations between albite in the wall-rock or in the fault zone. Albite replacing K-feldspar is riddled with micro-pores, inducing a turbid appearance at the optical microscope and a pinkish color at the hand sample.

\subsubsection{Epidote}

Epidote occurs either as an alteration product of K-feldspar in the wall-rock, damage and transitional zones, infill of microveins nucleating from the fault core and crosscutting the damage zone, or replacing minerals of clasts or as clasts in the fault core. Epidote has an Fe-rich composition, with $\mathrm{X}_{\mathrm{ep}}$ (i.e. $\left.\mathrm{Fe} /(\mathrm{Fe}+(\mathrm{Al}(\mathrm{VI})-2)) * 100\right)$ generally in the range 53-100, but locally preserving Al-rich composition $\left(X_{\mathrm{ep}}=46\right)$; epidote records a decrease from the core to the rim of $\mathrm{Si}, \mathrm{Ti}, \mathrm{Al}, \mathrm{Cr}, \mathrm{Mg}$, $\mathrm{Mn}, \mathrm{Ba}$ and an increase of Fe, Ca, Nd, Ce (Fig. 7). No significant chemical variation exists between epidote in the wall-rock or in the fault rock except for the core of epidote in the wall-rock that is richer in Mn compared to epidote occurring in other structural sites; locally this epidote is enriched in Ce and La. Locally, epidote is surrounded by allanite coronas and includes tiny zircons and sphene.

\subsubsection{Prehnite}

Prehnite occurs either as an alteration phase in the wall-rock, damage and transitional zones, the main consistituent of UCTs matrix or the infill of vugs and veins cutting the fault core; it occurs also in pseudotachylyte layers matrix. It is generally characterized by a compositional variation from the core to the rim, with $\mathrm{Fe}$, Ti and Mn decreasing, and $\mathrm{Si}$, $\mathrm{Al}$, Ca increasing, respectively, independently of the structural site where it occurs (Fig. 7). Mm-thick "veins" of prehnite rich in $\mathrm{Si}, \mathrm{Al}$ and poor in $\mathrm{Fe}$ and $\mathrm{Cr}$ randomly crosscut prehnite in vugs.

\subsubsection{White mica and chlorite}

White mica is a minor mineralogical phase in both the wall-rock and the fault zone. It replaces biotite and overgrows K-feldspar, occurring either as $\mu \mathrm{m}$ - (after K-feldspar) to hundreds of $\mu \mathrm{m}$-size (after biotite) crystals. White mica is a muscovite with two main high-Si compositions ( $\mathrm{Si}=5.94-6.17$ a. p.f.u.), being therefore somewhat more phengitic in composition than typical magmatic muscovite (Fig. 7). Crystals after biotite, growing with chlorite, have generally a higher $\mathrm{Fe}$ (and $\mathrm{Mg}$ ) content, whereas white mica replacing K-feldspar has lower $\mathrm{Mg}$ and Fe. In the $\left(\mathrm{Mg}+\mathrm{Fe}_{\text {tot }}\right)$ vs $\mathrm{Si}$ diagram, some white micas plot along the line representing the ideal celadonitic substitution, whereas others are shifted from it suggesting that a small amount of $\mathrm{Fe}^{3+}$ may be present.

Chlorite, occurring as some hundred $\mu \mathrm{m}$-size crystals, replaces biotite and overgrows K-feldspar in the wall-rock, damage and transitional zones; $\mu \mathrm{m}$-size chlorite was detected in the UCTs either in equilibrium with prehnite in the matrix or associated to K-feldspar clasts. Chlorite has been classified as pycnochlorite, having $\mathrm{Fe} /(\mathrm{Fe}+\mathrm{Mg})=0,4-0,6$.

\subsection{EBSD analyses}

\subsubsection{Epidote- and prehnite-rich UCTs}

As described in "Material and Methods", for the EBSD mapping, we selected two areas representative of two main domains of the studied structures, i.e. the epidote- and prehnite-rich UCT and the pseudotachylyte layers (Fig. 8).

In the UCT domain (Fig. 9), the EBSD phase map shows the occurrence of epidote-, prehnite- and K-feldspar-rich layers. K-feldspar-rich
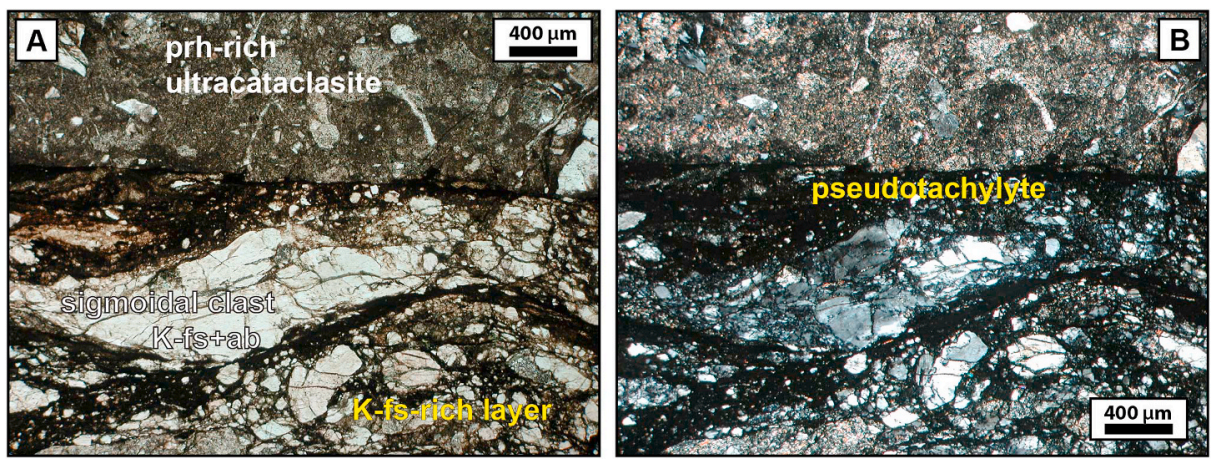

Fig. 6. A-B) Pseudotachylyte layers cutting UCTs and wrapping sigmoidal clasts made by wall-rock minerals (e.g. K-fs with ab tails); A: parallel polarized nicols; B: crossed polarized nicols. 


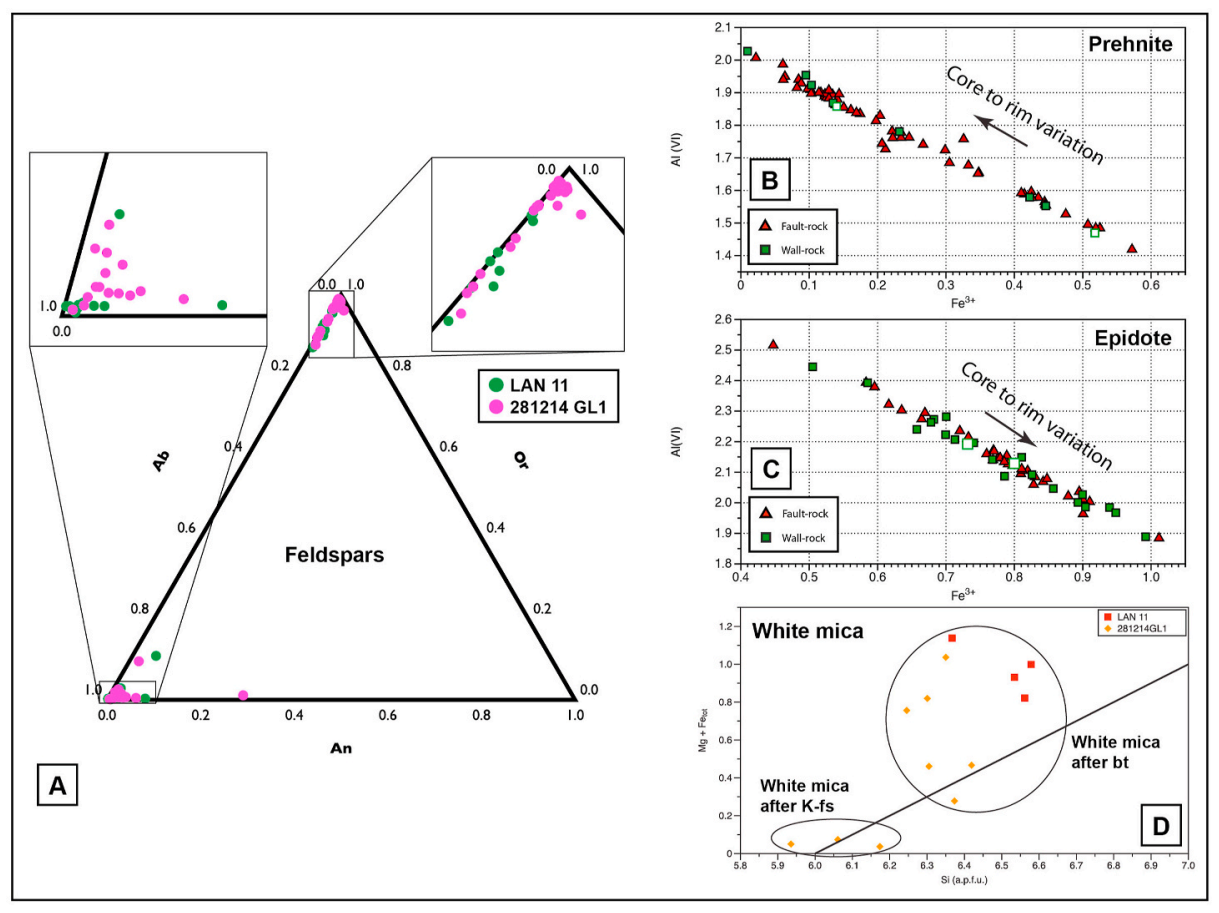

Fig. 7. Classification diagrams of representative minerals (i.e. A: feldspars, B: prehnite, C: epidote and D: white mica). Fig. 7A shows the composition of relict Caplagioclase, albite and K-feldspar.

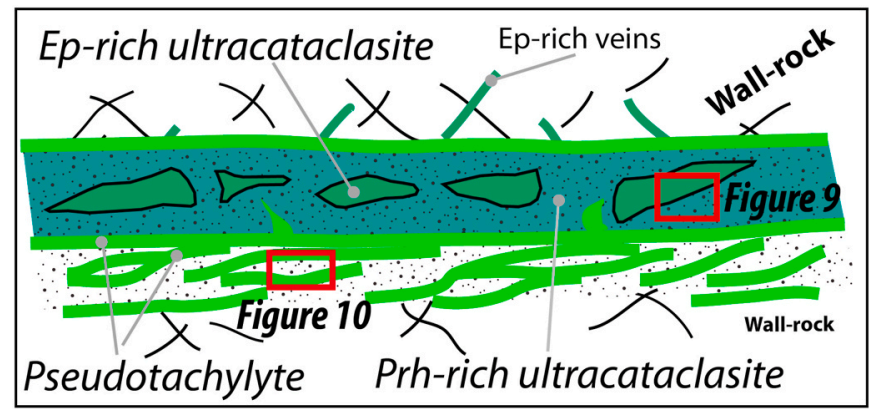

Fig. 8. Schematic representation of the studied damage zones with the location of sub-areas used for the EBSD maps of Figs. 9 and 10.

layers (i.e. mylonite relicts) include coarse-grained deformed K-feldspar (30-250 $\mu \mathrm{m}$-sized) with subgrains and mostly undeformed $10 \mu \mathrm{m}$-size grains (GOS mean $=0.71$; GOS median $=0.23$; GOS $\max =14.86$ ), as shown by phase maps in Fig. 9B. K-feldspar shows a strong CPO (Fig. 9E): the [100] axes are subparallel to the $\mathrm{Z}$ direction (i.e. normal to the $\mathrm{XY}$ plane and shear zone walls, Fig. 3A), with (100) being thus subparallel to the XY plane (i.e. foliation plane); (010)-poles are strongly concentrated around the $\mathrm{Y}$ direction, i.e., subparallel to the $\mathrm{XZ}$ plane (i. e., normal to the shear zone and parallel to the lineation, Fig. 3A). (001)poles suggest that the corresponding planes are subparallel to the $\mathrm{YZ}$ plane (i.e. almost normal to the fault zone walls) and therefore [001] are subparallel to the $\mathrm{X}$ direction. This $\mathrm{CPO}$ is consistent with a foliation marked by the alignment of (100) planes and a lineation defined by [001] axes.

Epidote occurs as weakly plastically deformed crystals (1), replaced by epidote (2) that is undeformed (GOS mean $=0.78$, GOS median $=$ 0.34 , GOS $\max =11.36$ ). Deformed epidote (1) develops subgrains. Both epidote (1) and (2) are randomly oriented (Fig. 9F).

Prehnite is present as coarse plastically deformed crystals, i.e. prehnite (1) which develop subgrains (GOS mean $=0,59$, GOS median $=$ 0,38 , GOS $\max =7,13$ ). Undeformed prehnite (2) replaces prehnite (1).
Both prehnite (1) and (2) are randomly oriented (Fig. 9G). The prehnite orientation maps reveals that a high amount of prehnite crystals has a tabular habit (see Supplementary Fig. 2).

Inside epidote- and prehnite-rich layers, clasts of deformed K-feldspar, albite, quartz and calcite have no significant crystallographic preferred orientation.

\subsubsection{Pseudotachylyte}

The most representative minerals, providing key information about texture of the pseudotachylyte layers are K-feldspar, albite and prehnite (Fig. 10A-D).

Coarser K-feldspar crystals are plastically deformed around the [001] axis (Fig. 10B), producing numerous subgrains (GOS mean $=1.01$, GOS median $=0.62$, GOS $\max =10.88)$. K-feldspar is characterized by a strong concentration of [100] axes, (010)- and (001)-poles (Fig. 10E): [100] axes are parallel to the $\mathrm{X}$ direction (i.e. maximum elongation direction, see Fig. 3A); (010) planes are subparallel to the XY plane; (001) planes are subparallel to the $\mathrm{XZ}$ plane (i.e. normal to the slip plane, Fig. 3A). This CPO is consistent with a foliation marked by the alignment of (010) planes and a lineation defined by [100] axes. The CPO of Kfeldspar in this area is almost orthogonal compared to the CPO observed in K-feldspar-rich layers preserved in UCTs (see previous paragraph; Fig. 9), possibly resulting from the activation of distinct slip systems.

Albite shows a quite strong concentration of [100] axes, (010)- and to a lesser extent (001)-poles, slightly rotated compared to those of Kfeldspar (Fig. 10F). Coarser albite crystals are deformed around several axes, consistent with the activation of multiple slip systems (GOS mean $=0.98$, GOS median $=0.58$, GOS $\max =12.82$ ).

Prehnite shows a weak but relatively well-defined CPO, with a maximum of the [001] axes (Fig. 10G) sub-parallel to the $\mathrm{Z}$ direction and therefore normal to the shear zone. In general, coarser prehnite is slighly plastically deformed (GOS mean $=0.70$, GOS median $=0.41$, GOS max $=9.21$ ) around the [010] axis (Fig. $10 \mathrm{D})$. 

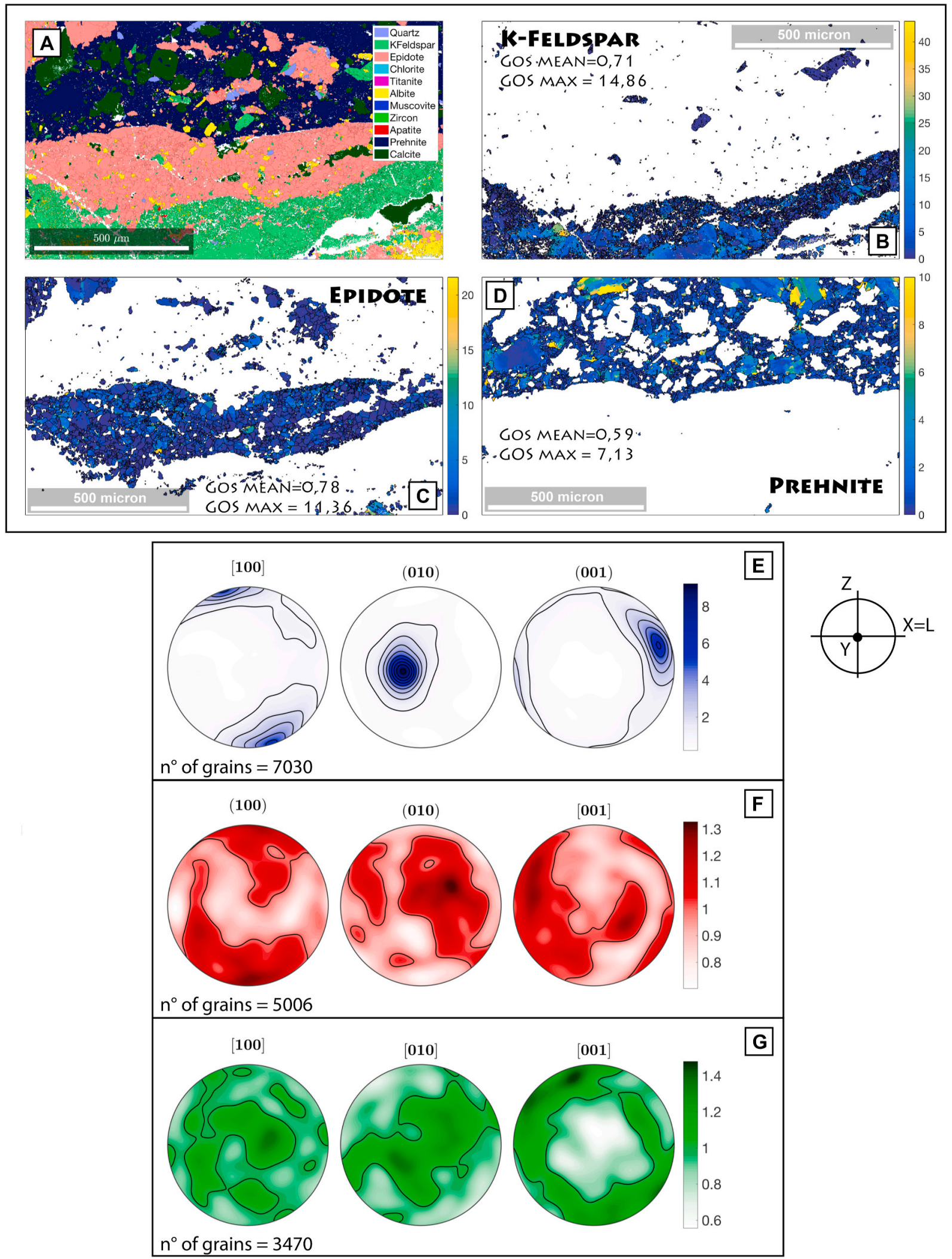

Fig. 9. EBSD analyses of LAN 11 sample. A) Phase map. B-C-D) Mis2mean of K-fs, ep and prh, respectively. E-F-G) Stereographic projections (one point per grain) of the crystallographic orientation of K-fs, ep and prh, respectively. Sections are parallel to $\mathrm{XZ}$ of the strain ellipsoid, where $\mathrm{X}$ is horizontal, $\mathrm{Z}$ is vertical, and $\mathrm{Y}$ is at the center of the pole figures. 

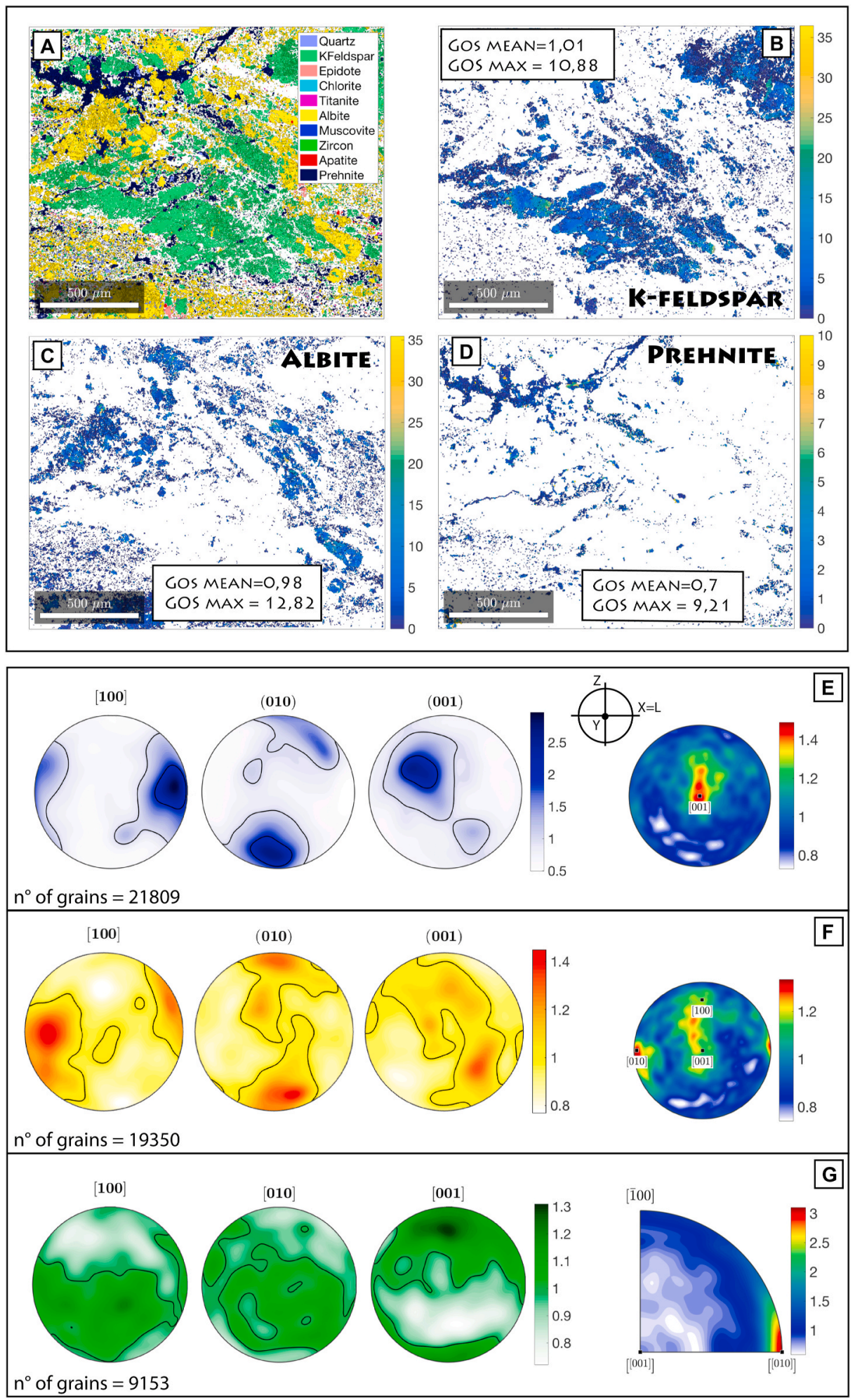

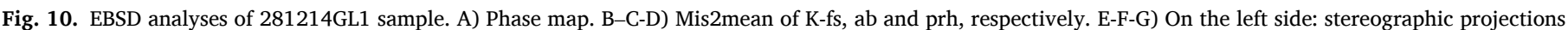

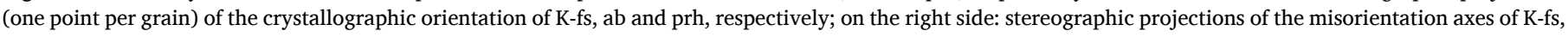
$\mathrm{ab}$ and prh, respectively. Sections are parallel to $\mathrm{XZ}$ of the strain ellipsoid, where $\mathrm{X}$ is horizontal, $\mathrm{Z}$ is vertical, and $\mathrm{Y}$ is at the center of the pole figures.

\section{Discussion}

\subsection{Alterations of wall- and fault-rock}

The microstructural and petrographical analysis of wall-rock and fault rocks highlighted that, during all the activity stages of the shear zone, fluids interacted with the rock leading to the alteration of primary magmatic minerals.

We detected three main types of alteration that produced typical hydrothermal associations (e.g. Ciesielczuk, 2007): (i) the albitization of K-feldspar and of Ca-plagioclase; (ii) the crystallization of calcite (mainly in veins); (iii) the alteration of magmatic phases by secondary 
hydrous minerals (e.g. chlorite, white mica, epidote and prehnite).

\section{(i) Albitization of K-feldspar and Ca-plagioclase}

Albitization was the first alteration process affecting the rock and probably occurred mainly in conjunction with a first ductile deformation event, as testified by albite-rich pressure shadows of K-feldspar porphyroclasts. Albite veins cutting albitized K-feldspar, however, suggest that this alteration was also synchronous to brittle deformation events, affecting the damage and transitional zones.

The pervasive replacement of K-feldspar and Ca-plagioclase by albite (i.e. albitization process) is a well-known phenomenon in both sedimentary basins and igneous and metamorphic rocks (e.g. Voll 1969; Saigal et al., 1988; Lee and Parsons, 1997; Holness, 2003). This process is thought to occur at low temperature during circulation of metasomatic fluids; in this case, albite is typically untwinned (except where it overgrowths twinned plagioclase), close to pure end-member composition, and is commonly highly microporous (e.g. Kastner and Siever 1979; Saigal et al., 1988; Holness, 2003). All these characteristics are applicable to our observations.

This replacement could occur according to the following reactions:

K-feldspar $+\mathrm{Na}^{+}=$albite $+\mathrm{K}^{+}$(e.g. Aagaard et al., 1990; Simpson and

Wintsch, 1989; Holness, 2003), or

1.0 Ca-plagioclase $+1.2 \mathrm{SiO}_{2}+0.6 \mathrm{Na}^{+}$

$=1.3$ albite $+0.3 \mathrm{Ca}^{2+}($ Ferry, 1979)

Reaction (1) could be triggered either by the influx of Na-rich fluids, or by a temperature gradient (infiltration of a cooler surface fluid in chemical equilibrium with the rock) in a lithology containing two alkali feldspar phases, where fluid flow results in redistribution of alkalis (Holness, 2003 and references therein).

Reaction (2) is favoured by the increase in $\mathrm{a}^{+} \mathrm{Na} / \mathrm{a}^{2+} \mathrm{Ca}$, which could have been achieved through (i) the precipitation of calcite in veins, and/ or (ii) flux of NaCl-rich brines, which were derived either from external sources (Barton and Johnson 1996) or exsolved from the granitic magma (Hay et al., 1988; Aslund et al., 1995; Morad et al., 2010).

Since we do not have sufficient evidence for the occurrence of two different alkali feldspars in our samples, we suppose that the possible explanation for the albititization process could be the influx of Na-rich fluids, which triggered the albititization of K-feldspar and possibly of Ca-plagioclase.

We moreover observed that K-feldspar and Ca-plagioclase are mostly albitized rather than saussuritized: the first process is thought to be most substantial in granitic rocks that contain little or no biotite (Morad et al., 2010) as in our case. In fact, the small amounts of chloritized biotite do not favour the formation of sericite and epidote, and hence results merely in albitization rather than saussuritization of plagioclase.

\section{(ii) Crystallization of calcite}

Calcite, now occurring either as clasts inside UCTs or in veins cutting UCTs, precipitated in veins along the main shear zone after ductile deformation, according to the reaction (Bruhn et al., 1994):

$\mathrm{Ca}^{2+}+\mathrm{CO}_{2}+\mathrm{H}_{2} \mathrm{O}=\mathrm{CaCO}_{3}$ (calcite) $+2 \mathrm{H}^{+}$

where the partial pressure of $\mathrm{CO}_{2}$ in the circulating fluid controlled the stability of calcite; a drop in fluid pressure, probably caused by fracturing, would have thus forced the boiling of the solution, the release of $\mathrm{CO}_{2}$-rich vapors, later favoring the precipitation of calcite (Bruhn et al., 1994; Lowenstern, 2001).

(iii) Alteration of magmatic phases by secondary hydrous minerals

The replacement of magmatic phases by secondary hydrous minerals (i.e. chlorite, white mica, epidote and prehnite) occurred at different stages during the evolution of the rock: chlorite, and possibly white mica, were pre-to post brittle-ductile events, whereas epidote and prehnite grew syn-to post-brittle-ductile and brittle deformations. This alteration process can be partly explained by the following reactions (Bruhn et al., 1994; Ciesielczuk, 2007):

$3 \mathrm{KAlSi}_{3} \mathrm{O}_{8}(\mathrm{~K}$-feldspar $)+2 \mathrm{H}^{+}=\mathrm{KAl}_{3} \mathrm{Si}_{3} \mathrm{O}_{10}(\mathrm{OH})_{2}($ white mica $)+2 \mathrm{~K}^{+}+$ $6 \mathrm{SiO}_{2}$ (quartz);

$2 \mathrm{KAlSi}_{3} \mathrm{O}_{8}\left(\mathrm{~K}\right.$-feldspar) $+5 \mathrm{Mg}^{2+}+8 \mathrm{H}_{2} \mathrm{O}=\mathrm{Mg}_{5} \mathrm{Al}_{2} \mathrm{Si}_{3} 0_{10}(\mathrm{OH})_{8}$ (chlorite) $+2 \mathrm{~K}^{+}+8 \mathrm{H}^{+}+3 \mathrm{SIO}_{2}$ (quartz);

$3 \mathrm{KAISi}_{3} \mathrm{O}_{8}(\mathrm{~K}$-feldspar $)+2 \mathrm{Ca}^{2+}+\mathrm{H}_{2} \mathrm{O}=\mathrm{Ca}_{2} \mathrm{Al}_{3} \mathrm{Si}_{3} \mathrm{O}_{12}(\mathrm{OH})$ (epidote) + $3 \mathrm{~K}^{+}+\mathrm{H}^{+}+6 \mathrm{SiO}_{2}$ (quartz);

biotite $+\mathrm{Ca}^{2+}+\mathrm{H}_{2} \mathrm{O}+\mathrm{H}^{+}=$chlorite + sphene $+\mathrm{H}_{4} \mathrm{SiO}_{4}+\mathrm{Fe}^{2+}+\mathrm{K}^{+}(7)$ Ca-plagioclase $+\mathrm{H}_{4} \mathrm{SiO}_{4}+\mathrm{Fe}^{2+}+\mathrm{K}^{+}=$white mica + prehnite $+\mathrm{H}_{2} \mathrm{O}+$ $\mathrm{H}^{+}$

The above reactions are driven by changes in temperature, pressure and fluid composi-tion. Reactions (4) to (6) describe the formation of low Mg-Fe white mica, chlorite and epidote replacing K-feldspar, and imply the interaction of magmatic minerals with metasomatic fluids rich in $\mathrm{Ca}$ and $\mathrm{Mg}$, where $\mathrm{Ca}$ was probably partially provided by the albitization reaction of Ca-plagioclase and $\mathrm{Mg}$ in part by biotite breakdown. In fact, biotite was in fact completely replaced by chlorite, sphene, and later prehnite and phengitic white mica, based on reactions (7) (8). The above reactions would cause the crystallization of new quartz if fluids are saturated with respect to quartz (Bruhn et al., 1994), which would explain the occurrence of new quartz in UCT layers cutting the transitional zone, indicating localized mobility of $\mathrm{SiO}_{2}$ during fault slip.

With decreasing $\mathrm{T}$ and/or $\mathrm{f}_{\mathrm{CO} 2}$, prehnite replaced epidote and calcite, based on the reaction:

calcite + epidote + quartz $+\mathrm{H}_{2} \mathrm{O}=$ prehnite $+\mathrm{CO}_{2}$ (Cho and Liou, 1987)(9)

allowing the introduction of a subsequent reaction to explain the chemical variation of epidote and prehnite (Fig. 7):

Fe-prehnite + Fe-poor epidote $=$ Al-prehnite + Fe-rich epidote $($ Harper, 1995) . (10)

According to what was experimentally observed by Liou et al. (1983) for the system $\mathrm{CaO}-\mathrm{FeO}-\mathrm{Fe}_{2} \mathrm{O}_{3}-\mathrm{Al}_{2} \mathrm{O}_{3}-\mathrm{SiO}_{2}-\mathrm{H}_{2} \mathrm{O}$, the $\mathrm{Fe}^{3+} /\left(\mathrm{Fe}^{3+}+\mathrm{Al}\right)$ ratio in epidote varies as functions of temperature, $\mathrm{P}_{\text {fluid }}$ and $\mathrm{f}_{\mathrm{O} 2}$. With decreasing temperature and more oxidizing conditions, epidote should be in fact enriched in $\mathrm{Fe}^{3+}$, as observed in epidote in our fault rock.

In general, the occurrence of Fe-rich epidote thus suggests formation conditions under elevated $\mathrm{f}_{\mathrm{O} 2}$ and low $\mathrm{P}_{\mathrm{CO} 2}$ (Liou et al., 1983). On the other side, a high $\mathrm{P}_{\mathrm{CO} 2}$ would favour the precipitation of carbonates, triggered by a drop in fluid pressure: the $\mathrm{CO}_{2}$ released after prehnite-in reaction (8) would have thus triggered the precipitation of calcite in new veins cutting prehnite-rich UCTs.

The hydrothermal alterations both of the wall- and fault-rock were thus triggered by the continuous interaction of the rock with metasomatic fluids, which occurred both during the ductile and the brittle deformation events. The movements along the superposed shear zones caused sufficient dilatation of grain boundaries and microcracks to generate an interconnected porosity and microcracks.

\subsection{Thermobaric conditions of deformation and fluid-rock interaction}

The P-T conditions at which ductile deformation started to affect the monzogranite/granodiorite can be roughly derived by information from both myrmekite textures, deformed quartz and microperthites in the damage and transitional zones, and relicts of mylonite preserved inside UCTs. Myrmekites in granitoids, testifying to the occurrence of stress- 
concentration sites during progressive deformation (Simpson and Wintsch, 1989), were inferred to develop mainly at upper greenschist to amphibolite facies conditions, even if there is no agreement on a precise estimate of temperature in the literature (i.e., $\mathrm{T} \geq 450-500{ }^{\circ} \mathrm{C}$; Harlov and Wirth, 2000; Wirth and Voll, 1987; Cesare et al., 2002; Menegon et al., 2006). The textures of quartz in the damage and transitional zones (e.g., subgrains, bulges testifying grain boundary migration, undulose extinction) suggest dynamic recrystallization and deformation temperatures in the range of $300-400{ }^{\circ} \mathrm{C}$ (Passchier and Trouw, 2005). $\mathrm{K}$-feldspar crystals in mylonite relicts suggest temperature of deformation of $\mathrm{T} \geq 400-450{ }^{\circ} \mathrm{C}$, which are the values at which this mineral become to be effectively plastically deformed (Fitzgerald and Stnitz, 1993) and references therein; (Menegon et al., 2008).

$\mathrm{CPO}$ of K-feldspar gives very few information about thermobaric conditions: experimental studies (Tullis, 1983 and references therein) and the analysis of recrystallized natural aggregates have shown that the most common active slip plane, over a wide range of temperature and pressures (500-800 $\left.{ }^{\circ} \mathrm{C} ; 2-8 \mathrm{kbar}\right)$, is (010) and that slip directions are [101], [100], [001] and [010] (e.g. Sacerdoti et al., 1980; Schulmann et al., 1996; Franek et al., 2006), in good accordance with the active slip system observed in K-feldspar wrapped by pseudotachylytes ([100] (010)). The CPO observed in K-feldspar from mylonite preserved in epidote- and prehnite-rich UCTs ([001] (100)) does not fit with any of the known active slip systems, being orthogonal to that of mylonites in UCTs. The different slip systems observed in UCTs and pseudotachylytes, respectively, could be probably related either to different deformation mechanisms (e.g., dislocation creep vs dissolution-precipitation creep), that acted in the same range of P-T conditions (mid-crustal conditions) (Menegon et al., 2008) or to a combination of a creep (i.e. dissolution-precipitation creep) with rigid body rotation of mineral grains, that produced a CPO in a deforming aggregate at low shear strain values (Bons and den Brok, 2000; Menegon et al., 2008).

Based on our observations, we therefore propose that deformation within the ductile shear zone occurred at temperatures around $400{ }^{\circ} \mathrm{C}$, i. e. at upper greenschist facies conditions, suggested also by the presence of microperthites in K-feldspar (Passchier and Trouw, 2005).

The thermobaric conditions of fluid-rock interaction during ductile and brittle-ductile deformation can instead be derived from the conditions of formation of albite pressure shadows of K-feldspar preserved in UCTs and of albite microveins (i.e. albitization process). Albitization of primary minerals or Na-metasomatism occur in granites at $\mathrm{T} \leq 450{ }^{\circ} \mathrm{C}$ (Petersson and Eliasson, 1997; Kaur et al., 2012; Lee and Parsons, 1997; Nijland and Touret, 2001; Boulvais et al., 2007). The precipitation of calcite, probably in veins, occurred after the development of ductile shear zones, and therefore at $\mathrm{T}<400{ }^{\circ} \mathrm{C}$.

The fluid-rock interaction conditions, at which secondary hydrous minerals formed, is constrained at high temperatures by biotite breakdown reaction to form chlorite (post-ductile), that is thought to occur below approximately $400{ }^{\circ} \mathrm{C}$ (Spear, 1993). The formation of secondary alteration minerals continued at brittle-ductile and brittle conditions with the crystallization of white mica, epidote and prehnite. Hydrothermal mineral assemblages similar to what we observed in the fault rock (i.e. chlorite, epidote and white mica) give temperatures between 300 and $350^{\circ} \mathrm{C}$ (Bruhn et al., 1994), at low greenschist facies conditions; this temperature range agrees with the values proposed for the formation of Fe-rich epidote (Liou et al., 1983). The phengitic composition of white mica after biotite points to a high temperature of crystallization (Morad et al., 2010), confirming its formation in a hydrothermal system (Dempster et al., 1994; Gomes and Neiva 2000; Viana et al., 2007).

The stability conditions of prehnite are instead well constrained by the prehnite-in reaction at $\mathrm{T}<350^{\circ} \mathrm{C}(2-8 \mathrm{kbar})$ (Liou et al., 1983) and by the reaction for breakdown of prehnite to laumontite (the latter not observed in our rock), at $\mathrm{T}=200^{\circ} \mathrm{C}$ (Rusinov, 1965).

The metasomatic reactions observed in our wall- and fault rock thus suggest that the fluid-rock interaction started roughly at $\mathrm{T} \leq 450{ }^{\circ} \mathrm{C}$ (i.e. albitization) during ductile deformation and it continues to act with decreasing temperature in a brittle environment, until at least the crystallization of prehnite $\left(\mathrm{T}>200{ }^{\circ} \mathrm{C}\right)$.

\subsection{Model for fault zone evolution}

The studied fault zone recorded several activation steps, each one characterized by pervasive fluid-rock interaction and by hydrothermal alteration affecting both the damage and transitional zones, and the fault core (Fig. 11).

As testified by mylonite clasts with deformed K-feldspar in UCTs, a possibly sub-(?) cm-thick mylonitic shear zone in the monzogranite/ granodiorite, possibly nucleating on some surface precursors (e.g. fractures or compositional layers) (Pennacchioni and Mancktelow, 2018), acted as a "weak" zone along which the fault later developed (T0, Fig. 11). The formation of the main mylonitic shear zone and of the minor shear zones in the present damage zone was followed by the circulation of metasomatic fluids, causing the progressive alteration of wall-rock minerals first by albite and later by secondary hydrous phases (e.g. chlorite, white mica, epidote, prehnite) (T0, Fig. 11). The following brittle-ductile to brittle stages, at progressively decreasing temperature conditions, were recorded in the shear zone:

i) $\mathrm{CO}_{2}$-rich fluid-assisted precipitation of calcite in veins along the mylonitic shear zone (T1, Fig. 11): the occurrence of calcite clasts replaced by epidote and prehnite suggests that calcite veins were present before the development of epidote-rich UCTs. The calcite veins could have acted therefore as another weak surface in the rock, which was later used by the fault.

(ii) epidote (1)-rich UCTs and epidote-rich veins formation; later dynamic crystallization of epidote (2) with alteration of wall-rock minerals (T2A-T2B, Fig. 11); several hypotheses can be proposed to explain the genetic mechanism of epidote-rich UCTs:

(a) formation of a major epidote (1)-filled vein and minor epidote veins in the former wall-rock;

(b) formation of a metasomatic alteration halo in the former wall-rock, in which epidote (1) overgrew primary minerals after the localized percolation of fluids in microfractures;

(c) development of an UCT in the rock along the mylonitic shear zone, and subsequent interaction with fluids that caused the formation of epidote (1) replacing first the matrix of UCT and later the clasts.

We propose that hypothesis (c) is the most likely (i.e., UCT interacting with fluids): the interaction of percolating fluids with the numerous reactive surfaces available after the occurrence of microfractures (b) or cataclasis (c) would have caused the almost complete alteration of the rock minerals by epidote, preserving only some relicts or clasts; however, the occurrence of microcracks filled by epidote in the present damage zone seems to be more compatible with the formation of a former UCT (c). Moreover, this hypothesis matches the occurrence of calcite clasts pertaining to a former vein that was possibly fragmented by the fault. We exclude the first hypothesis (a) because the wall-rock mineral relicts and the calcite clasts, which are still inside the epidoterich layers, should be fragments of the vein walls, which is poorly probable if the layers were related to a major vein.

The continuous shearing along the fault later caused the deformation of epidote (1) and the crystallization of epidote (2).

(iii) Boudinage of epidote-rich UCTs and formation of prehnite-rich UCTs (T3A, Fig. 11): the ongoing brittle-ductile deformation along the fault caused the boudinage of epidote-rich layers and the involvement of increasing volumes of the host-rock, with the formation of new UCTs. The matrix of UCTs was gradually replaced mainly by post-kinematic prehnite after the continuous interaction with fluids. 


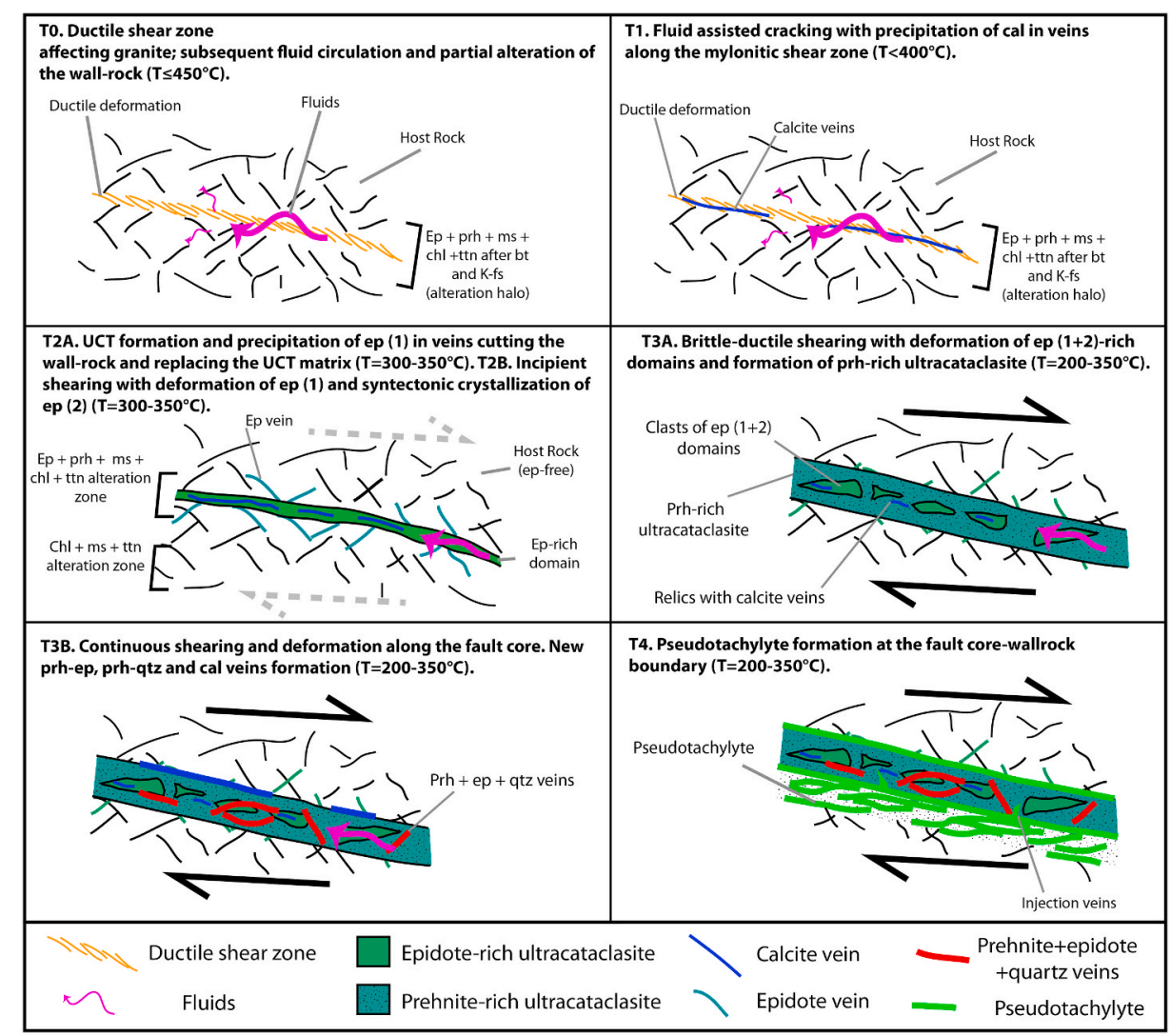

Fig. 11. Conceptual sketch model for the evolution of the studied fault zones. See text for explanation.

The cyclic activation of the fault and its more and more pervasive activity produced the repeated boudinage of the fault core, the plastic deformation of former prehnite (1) crystals and the formation of different generations of prehnite-rich UCTs with increasingly smaller clasts and prehnite (2) crystals.

(iv) Formation of prehnite-epidote-quartz/calcite veins (T3B, Fig. 11): veins/vugs, hosting prehnite, epidote and quartz crystals, probably opened either after the increase in pore fluid-pressure that reduced the brittle strength of the grains aggregate (Philippot and van Roermund, 1992; Malatesta et al., 2018b) or in response of fault-related dilation. New veins, filled by calcite, later opened after the presence of $\mathrm{CO}_{2}$-rich fluids. The possible increase in pore fluid-pressure can be either related to the deformation-induced grain-size reduction of the fault core (Caine et al., 1996) or to the crystallization of prehnite in UCT matrix; both can in fact decrease the permeability by sealing off the pore spaces (Philippot and Selverstone, 1991).

(v) Pseudotachylyte formation at the fault core-wall rock boundary (T4, Fig. 11): the fault zone was finally affected by possibly coseismic slip that caused the comminution of part of the fault rock and of the wall-rock, with the formation of pseudotachylyte layers of crushing origin at the fault core-wall rock boundary, showing micro-injection veins and sharp contacts with UCTs. In the pseudotachylyte, prehnite in the matrix is weakly oriented, showing a preferred orientation of the [001] axes normal to the fault zone walls: this could suggest a passive orientation of prehnite crystals during fluidal flux of ultra fine-grained material.

The rapid fluidization along pseudotachylyte layers, as observed at several fault zones worldwide (Lin, 2011), is also suggested by the dramatic grain size decrease of prehnite in pseudotachylytes (sub- $\mu \mathrm{m}$ size) compared to UCTs (10-80 $\mu \mathrm{m}$-size) and by the strong grain size reduction of wall-rock material in pseudotachylyte matrix (sub- $\mu \mathrm{m}$ to $\mu \mathrm{m}$-size clasts). The presence of comparable textures in pseudotachylyte layers and in injection vein filling material suggests the possible presence of fluids during pseudotachylyte formation. In contrast, if pseudotachylytes formed at dry conditions, we would have expected different textures for the material inside the injection veins and in the layers, respectively (i.e. a stronger orientation of prehnite in the layers compared to prehnite in the injection veins).

Fault rocks characterized by injection veins of fine-grained and ultrafine-grained material have been globally observed, for example pseudotachylytes of crushing origin with little or no direct evidence for melting, fault breccia zones, ultracataclastic veins generated by coseismic comminution with little melting, accompanied by rapid fluidization in the coseismic shear zone, micro-injection veins of fault gouge (Sibson, 1986; Lin, 1996, 2011; Janssen et al., 2010) and have been related to seismic events. The correlation of seismic events and the comminution and grain-size reduction through pulverization along a fault plane has been documented by natural evidence (e.g., Ujiie, 2007; Lin 2011; Rowe et al., 2012), and by experimental works (e.g., Mizoguchi et al., 2007). Recently, Fondriest et al. (2020) documented experimentally that fluids percolation and strong hydrothermal alteration in exhumed faults can transform pseudotachylytes into apparent cataclastic to ultracataclastic injection veins.

Indeed, the conversion of the kinetic energy of comminution during seismic slip to heat (Rice, 2006) produce the thermal expansion of the fluids present along the fault, as well as the ultrafine- and fine-grained materials along the principal zone of slip; they become fluidized to form a gas-solid-liquid system that migrated into fractures under the high thermal fluid pressure within the fault zone (Lin, 1996, 2008, 2011, 2019; Ujiie, 2007); micro-injection veins may represent hydraulic fracturing normal to the least principal stress (Ujiie, 2007). As observed in other coseismic fault zones (Lin, 2011) and in experimental work (Mizoguchi et al., 2007), the coseismic slip and the fluidization were 
very localized and focused in a mm-wide layer $(<5 \mathrm{~mm})$. However, experiments on granitoid cataclasites under mid-crustal conditions showed that pseudotachylytes form also at slow creep and that they are therefore not necessarily correlated with earthquake occurrences (Pec et al., 2012).

The aforementioned results have important implications on the ongoing investigations and still debated polyphasicity of the longlived fault systems in this part of the Transantarctic Mountains. As outlined before, the Lanterman Fault-Rennick Graben Fault system represents a long-lived structural element in the nVL crust, which experienced multiple phases of activities from the late Ediacaran-early Paleozoic Ross Orogeny up to Recent times (Capponi et al., 1999; Rossetti et al., 2003; Storti et al., 2006; Crispini et al., 2007; Dubbini et al., 2010; Federico et al., 2010). The present structural architecture of the Lanterman Fault-Rennick Graben Fault system can be related to regional NNW-SSE to NW-SE trending brittle dextral strike-slip faulting that affected the nVL crust in the Cenozoic (Rossetti et al., 2002, 2003). Strain partitioning along this system, which transects nVL from the coast at the Pacific Ocean into the Ross Sea (Fig. 1), triggered the formation of the Rennick Graben as a narrow basin in extensional/transtensional domains and km-scale uplifted blocks in domains of local transpression, as for example in the Lanterman Range (Rossetti et al., 2002). Our results demonstrate that brittle dextral strike-slip faulting and E-W directed extension along the Cenozoic Lanterman Fault-Rennick Graben system postdates older fault structures and the epidote/prehnite fault vein mineralizations described in this study. Therefore, our results indicate the presence of co-seismic slip and syntectonic fluid flow pre-dating Cenozoic brittle reactivations of inherited structures along the Lanterman Fault-Rennick Graben Fault system. This may - at least in some part - question the scenario given by Di Vincenzo et al. (2013), who proposed a more than $390 \mathrm{Ma}$ long period of apparent tectonic quiescence and no obvious co-seismic slip along faults on the western Ross Sea rift shoulder between the late Ordovician/early Silurian and the Eocene. However, syntectonic fault vein formation and faulting may in fact be linked to either late solid-state deformation of the host granitoid rock in the early Paleozoic, or it may relate to even much younger tectonics affecting $\mathrm{nVL}$ in the middle to late Paleozoic and the Mesozoic. In fact, the presence of regional post-Ross-orogenic tectonism connected with increased fluid flow, elevated geothermal gadients and/or fault reactivation of inherited anisotropies has in fact been proposed by several authors for the Devonian-Carboniferous, the Permian, the Jurassic, and the Cretaceous (e.g., Walker, 1983; Tessensohn, 1994; Capponi et al., 1999; Molzahn et al., 1999; Fleming et al., 1999; Lisker et al., 2006; Läufer et al., 2006; Lisker and Läufer, 2013; Elliot et al., 2017). However, since robust geochronological data as well as combined petrological, geo- and isotope-chemical data of the studied fault veins and related structures are still not widely available, a more precise timing and a link to distinct tectonic regional events or further indications on source and evolution of the fluids cannot be given here so far.

\subsection{Implications on fault mechanics}

The multiple activity stages along the core of the studied cm-thick fault, as observed by cross-cutting relationships between the different generations of UCTs, microveins and pseudotachylytes, were characterized by periods of seismic slip, cyclically alternating with the cementation of microveins and UCTs matrix after the crystallization of hydrothermal minerals (i.e. calcite, epidote and prehnite) in the permeable fault core. In this context, UCTs and pseudotachylytes possibly represent episodes of seismic rupture of the fault (Chester and Chester, 1998; Lin, 2011), and the transition from UCTs to pseudotachylytes may be the record of an abrupt change in the magnitude of shear strain with increasing displacement along the fault (keeping other parameters as constant) (Chester and Chester, 1998).

The fault experienced several episodes of weakening and hardening, at gradually decreasing temperature conditions: cataclasis, which progressively reduces the grain size, is generally considered to produce strain softening (Steffen et al., 2001); episodes of cataclasis alternated with episodes of cementation of the matrix, the latter of which caused strain hardening (Ramsay, 1967).

The first episode of strain hardening was the crystallization of epidote (1) partly replacing the UCTs matrix. The following dynamic crystallization of epidote (2), probably by fluid-assisted grain boundary diffusion creep, caused a subsequent weakening, which was used by the new slip with the formation of new UCTs accompanied by percolation of fluids. The precipitation of prehnite crystals intergrown with clasts of the host rock, cyclically "locked" the fault (fault hardening), shifting deformation to weaker horizons (e.g. fault core-wallrock contact) and causing the progressive broadening of the fault zone.

Rocks that deform by grain reorganization (denser packing) and cataclasis develop fault planes, which are stronger than the surrounding (strain hardening) and produce broader fault rocks as movement continues (Sverdrup et al., 1997).

The presence of prehnite as mineral within the matrix and in veins, occupying about $30-40 \%$ of the fault core, should play a major role in affecting the fault movement. Prehnite is in fact a layer silicate (Deer et al., 2013), and experiments have revealed the weakening behaviour of phyllosilicates, especially in water-saturated conditions, which can also enhance surface displacement (Smeraglia et al., 2017). So, a new fault slip event should initiate within phyllosilicate-rich regions in wet conditions. In this study, however, we observed that pseudotachylyte veins, i.e. possibly seismic slip, developed still at the contact between the fault core and the wallrock. We suggest that the relatively low amount of prehnite (and its texture) played a major role in this context, not favoring the localization of slip along UCTs horizons. As observed for chlorite-rich fault rocks (Fagereng and Ikari, 2020), a higher volume fraction of prehnite could have instead focused deformation inside prehnite-rich UCTs.

\section{Conclusions}

We provide a microstructural, mineralogical and petrological study of a fault rock, representing an exhumed fault zone in monzogranite/ granodiorite of the Granite Harbour Intrusives of nVL in Antarctica. This fault zone belongs to the Lanterman Fault-Rennick Graben Fault system and was affected by pervasive hydrothermal fluid-rock interaction processes, which triggered multiple episodes of brittle slip and produced crosscutting UCTs and pseudotachylyte layers of crushing origin. The slip zone used a pristine mylonitic shear zone that acted as preferential pathway for fluid infiltration. The $\mathrm{Na}-\mathrm{CO}_{2}$-rich percolating fluid, produced the progressive albitization and later alteration of the host-rock minerals by chlorite, white mica, epidote and prehnite and the precipitation of epidote in microveins cutting the damage zone.

The reaction of hydrothermal fluids during interslip periods with the highly porous matrix of UCTs caused the crystallization of epidote and prehnite, resulting in the decrease of fault core permeability and its embrittlement, testified by prehnite-bearing veins. The fault was hence marked by cyclic softening (after cataclasis) and strengthening of the fault core after the crystallization of epidote and prehnite, thus possibly leading to alternating episodes of seismic rupture to interseismic periods characterized by a strong fluid-rock interaction, which facilitated the next seismic slip event. Pseudotachylytes possibly represent stronger seismic slip events that produced considerable grain size reduction, formation of injection veins and fluidal structures in the ultra-finegrained matrix. In this regard, it may be hypothesized that some pseudotachylites could be related to a lack or reduction of hydrothermal processes and consequently greater accumulation of strain prior to a larger rupture (cf. Heinicke et al., 2009). This example shows how several deformation events, first ductile and later brittle, can be concentrated and strongly localized in a relatevely thin (i.e. multiple $\mathrm{cm}$-thick) shear zone.

The hydrothermal fluids, interacting with the rock during both 
ductile and brittle shear episodes, recorded gradually decreasing temperature (from $\mathrm{T} \leq 450{ }^{\circ} \mathrm{C}$ ) and varying $\mathrm{CO}_{2}$ fugacity, as testified by the different alteration processes observed.

This study proves how the interplay between syntectonic alteration of mineral and precipitation of new minerals in the damage zone can control fault rheology. The precipitation of randomly growing weaker minerals such as phyllosilicate/prehnite produced hardening rather than softening. This suggests that the amount of secondary weaker minerals, their texture and the fluid content play an important role as well in the control of the fault rheology.

From a regional perspective, our results indicate that co-seismic slip and syntectonic fluid flow occurred prior to Cenozoic brittle reactivation of inherited anisotropies in the nVL crust along the Lanterman FaultRennick Graben Fault system. The results further demonstrate the high potential of the crust for polyphase reactivation of pre-existing discontinuities in the Ross orogenic-age basement units and the younger, post-Ross-orogenic rocks in nVL.

\section{Declaration of competing interest}

The authors declare that they have no known competing financial interests or personal relationships that could have appeared to influence the work reported in this paper.

\section{Acknowledgements}

The Authors acknowledge the logistical and financial support provided by the Italian National Antarctic Research Programme PNRA (PNRA2013/AZ2.02 and PNRA2016_00040-REGGAE projects) and the GANOVEX research program of the Federal Institute for Geosciences and Natural Resources, BGR, Hannover, Germany. Fieldwork in Antarctica was excellently supported by pilots of the Helicopter NZ Ltd and HSI Heli Support International Ltd. C.M. benefitted of a grant cofunded by the University of Genoa and the PNRA (PNRA2016_00040-REGGAE). F. L. and A.L. acknowledge funding by Deutsche Forschungsgemeinschaft (DFG) within the frame of the Collaborative Research Programme SPP 1158 'Antarctic Research with comparative investigations in Arctic ice areas' (grants LI 745/26 to FL and LA1080/19 to AL). We thank Ake Fagereng and an anonymous reviewer for constructive comments and suggestions, which considerably improved the manuscript. The scientific results of fault-slip analysis were obtained using the Win-Tensor software developed by Dr. Damien Delvaux, Royal Museum for Central Africa, Tervuren, Belgium (Delvaux and Sperner, 2003).

\section{Appendix A. Supplementary data}

Supplementary data to this article can be found online at https://doi. org/10.1016/j.jsg.2021.104350.

\section{CRediT author statement}

Malatesta: conceptualization,methodology,investigation, data curation, writing-original draft, writing-review and editing, visualization. Crispini: conceptualization,methodology,investigation,resources, data curation, writing-original draft, writing-review and editing, visualization, supervision, project administration, funding acquisition. Ildefonse: methodology, software,validation,formal analysis,resources, data curation, writing-review and editing. Federico: writing-review and editing. Lisker: investigation,conceptualization. Läufer: conceptualization, methodology, investigation, resources, data curation, writingoriginal draft, writing-review and editing.

\section{References}

Aagaard, P., Egeberg, P.K., Saigal, G.C., Morad, S., Bjrlykke, K., 1990. Diagenetic albitisation of detrital K-feldspars in Jurassic, Lower Cretaceous and Tertiary clastic reservoir rocks from offshore Norway. II. Formation water chemistry and kinetic considerations. J. Sediment. Petrol. 60, 575-581.

Arancibia, G., Fujita, K., Hoshino, K., Mitchell, T.M., Cembran, J., Gomila, R., Morata, D., Faulkne, D.R., Rempe, M., 2014. Hydrothermal alteration in an exhumed crustal fault zone: testing geochemical mobility in the Caleta Coloso Fault, Atacama Fault System, Northern Chile. Tectonophysics 623, 147-168.

Armienti, P., Ghezzo, C., Innocenti, F., Manetti, P., Rocchi, S., Tonarini, S., 1990. Isotope geochemistry and petrology of granitoid suites from granite harbor intrusives of the Wilson terrane, northern Victoria Land, Antarctica. Eur. J. Mineral 2, 103-123.

Aslund, T., Oliver, N.H.S., Cartwright, I., 1995. Metasomatism of the revenue granite and aureole rocks, Mt Isa Inlier, Queensland; syndeformational fluid flow and fluid-rock interaction (in Mid- to lower-crustal metamorphism and fluid-rock interaction, with reference to the Mt. Isa Inlier). Aust. J. Earth Sci. 42, 291-299.

Barton, M.D., Johnson, D.A., 1996. Evaporitic-source model for igneous- related Fe oxide - (REE-Cu-Au-U) mineralization. Geology 24, 259-262.

Black, L.P., Sheraton, J.W., 1990. The influence of Precambrian source components on the U-Pb zircon age of a Palaeozoic granite from northern Victoria Land, Antarctica. Precambrian Res. 46, 275-293.

Blenkinsop, T.G., Sibson, R.H., 1992. Aseismic fracturing and cataclasis involving reaction softening within core material from the Cajon Pass drill hole. Journal of Geophysical Research - Solid Earth 97 (B4), 5135-5144. https://doi.org/10.1029/ 90JB02285.

Bons, P., den Brok, B., 2000. Crystallographic preferred orientation development by dissolution-precipitation creep. J. Struct. Geol. 22, 1713-1722.

Borg, S.G., Stump, E., 1987. Paleozoic magmatism and associated tectonic problems of Northern Victoria Land, Antarctica. In: McKenzie, G. (Ed.), Gondwana Six: Structure, Tectonics and Geophysics, vol. 40. American Geophysical Union. Geophysical Monograph, pp. 67-76.

Borg, S.G., Stump, E., Chappell, B.W., McCulloch, M.T., Wyborn, D., Armstrong, R.L., Holloway, J.R., 1987. Granitoids of northern Victoria Land, Antarctica; implications of chemical and isotopic variations to regional crustal structure and tectonics. Am. J. Sci. 287, 127-169. https://doi.org/10.2475/ajs.287.2.127.

Boulvais, P., Ruffet, G., Cornichet, J., Mermet, M., 2007. Cretaceous albitization and dequartzification of hercynian peraluminous granite in the salvezines massif (French pyrénées). Lithos 93, 89-106.

Bracciali, L., Di Vincenzo, G., Rocchi, S., Ghezzo, C., 2009. The Tiger Gabbro from northern Victoria Land, Antarctica: the roots of a island arc within the early Palaeozoic margin of Gondwana. Journal of Geological Society London 166, 711-724.

Bradshaw, J.D., Laird, M.G., 1983. The pre-Beacon geology of Northern Victoria Land: a review. In: Oliver, R.L., James, P.R., Jago, J.B. (Eds.), Antarctic Earth Sciences. Australian Academy of Science, Canberra, pp. 98-101.

Bradshaw, J.D., Begg, J.C., Buggish, W., Brodie, C., Tessensohn, F., Wright, T.O., 1985. New data on Paleozoic stratigraphy and structure in north Victoria Land. N. Z. Antarct. Rec. 6 (3), 1-6.

Bruhn, R.L., Parry, W.T., Yonkee, W.A., Thompson, T., 1994. Fracturing and hydrothermal alteration in normal fault zones. PAGEOPH 142 (3/4), 609-644.

Caine, J.S., Evans, J.P., Foster, C.B., 1996. Fault zone architecture and permeability structure. Geology 24, 1025-1028.

Callahan, O.A., Eichhubl, P., Olson, J.E., Davatzes, N.C., 2019. Fracture mechanical properties of damaged and hydrothermally altered rocks, Dixie Valley-Stillwater fault zone, Nevada, USA. Journal of Geophysical Research - Solid Earth 124 (4), 4069-4090.

Capponi, G., Meccheri, M., Musumeci, G., Pertusati, P.C., Ricci, C.A., Talarico, F., 1994. A geological transect through the wilson-bowers-robertson Bay terranes junction (northern Victoria Land, Antarctica). P.N.R.A.-IX Italian antarctic expedition. Field Data Reports 16-19.

Capponi, G., Castelli, D., Fioretti, A.M., Oggiano, G., 1997. Geological mapping and field relationships of the eclogites from the Lanterman Range, northern Victoria Land, Antarctica. In: Ricci, C.A. (Ed.), The Antarctic Region: Geological Evolution and Processes. Terra Antarctica Publications, Siena, pp. 219-225.

Capponi, G., Crispini, L., Meccheri, M., 1999. Structural history and tectonic evolution of the boundary between the Wilson and Bowers terranes, lanterman range, northern Victoria Land, Antarctica. Tectonophysics 312, 249-266.

Cavailhes, T., Soliva, R., Labaume, P., Wibberley, C., Sizun, J.P., Gout, C., Charpentier, D., Chauvet, A., Scalabrino, B., Buatier, M., 2013. Phyllosilicates formation in faults rocks: implications for dormant fault-sealing potential and fault strength in the upper crust. Geophys. Res. Lett. 40, 4272-4278.

Cesare, B., Marchesi, C., Connolly, J.A.D., 2002. Growth of myrmekite coronas by contact metamorphism of granitic mylonites in the aureole of Cima di Vila, Eastern Alps, Italy. J. Metamorph. Geol. 20, 203-213.

Chester, F.M., Chester, J.S., 1998. Ultracataclasite structure and friction processes of the Punchbowl fault, San Andreas system, California. Tectonophysics 295, 199-221.

Chiodini, G., Cardellini, C., Di Luccio, F., Selva, J., Frondini, F., Caliro, S., Rosiello, A., Beddini, G., Ventura, G., 2020. Correlation between tectonic $\mathrm{CO}_{2}$ Earth degassing and seismicity is revealed by a 10 -year record in the Apennines, Italy. Science Advances 6, 35.

Cho, M., Liou, J.G., 1987. Prehnite- pumpellyite to greenschist facies transition in the Karmutsen metabasites, Vancouver Island, B.C. J. Petrol. 28 (3), 417-443.

Choi, J.H., Edwards, P., Ko, K., Kim, Y.S., 2016. Definition and classification of fault damage zones: a review and a new methodological approach. Earth Sci. Rev. 152, 70-87.

Ciesielczuk, J., 2007. Hydrothermal activity in the Strzelin granite (Poland). Granitoids in Poland. AM Monograph No 1, 231-242, 2007. 
Collettini, C., Viti, C., Smith, S.A.F., Holdsworth, R.E., 2009. The development of interconnected talc networks and weakening of continental low-angle normal faults. Geology 37, 567-570.

Crispini, L., Capponi, G., 2002. Albitite and listvenite in the Lanterman Fault zone (northern Victoria Land, Antarctica). In: Gamble, J., Skinner, D.N.B., Henrys, S. (Eds.), Antarctica at the Close of a Millennium, vol. 35. Ministry of Education, Wellington, New Zealand, pp. 113-119.

Crispini, L., Di Vincenzo, G., Palmeri, R., 2007. Petrology and Ar-Ar dating of shear zones in the Lanterman Range (northern Victoria Land, Antarctica): implications for metamorphic and temporal evolution at terrane boundaries. Mineral. Petrol. 89, 217-249.

Crispini, L., Federico, L., Capponi, G., Talarico, F., 2011. The Dorn gold deposit in northern Victoria Land, Antarctica, Structure, hydrothermal alteration, and implications for the Gondwana Pacific margin. Gondwana Res. 19, 128-140.

Crispini, L., Federico, L., Capponi, G., 2014. Structure of the millen schist belt (Antarctica): clues for the tectonics of northern Victoria Land along the paleo-pacific margin of gondwana. Tectonics 33, 420-440. https://doi.org/10.1002/ 2013 TC003414.

Crispini, L., Capponi, G., Läufer, A., Lisker, F., 2018. Fault-controlled ancient hydrothermal systems in north Victoria Land, Antarctica. In: Proceedings of the POLAR 2018 - where the Poles Come Together, Open Science Conference, Davos, Switzerland, 19-23 June 2018, 2106.

Deer, W.A., Frs, Howie R.A., Zussman, J., 2013. An Introduction to the Rock-Forming Minerals, third ed. Mineralogical Society of Great Britain and Ireland. https://doi. org/10.1180/DHZ.

Delvaux, D., Sperner, B., 2003. Stress tensor inversion from fault kinematic indicators and focal mechanism data: the TENSOR program. In: Nieuwland, D. (Ed.), New Insights into Structural Interpretation and Modelling, vol. 212. Geological Society, London, pp. 75-100. Special Publications.

Dempster, T.J., Tanner, P.W.G., Ainsworth, P., 1994. Chemical zoning of white micas: a record of fluid infiltration in the Oughterard granite, western Ireland. Am. Mineral. 79 (5-6), 536-544.

Di Vincenzo, G., Rocchi, S., 1999. Origin and interaction of mafic and felsic magmas in an evolving late orogenic setting: the Early Paleozoic Terra Nova Intrusive Complex, Antarctica. Contrib. Mineral. Petrol. 137, 15-35.

Di Vincenzo, G., Palmeri, R., Talarico, F., Andriessen, P.A.M., Ricci, C.A., 1997. Petrology and geochronology of eclogites from the lanterman range, Antarctica. J. Petrol. 38, 1391-1417.

Di Vincenzo, G., Rocchi, S., Rossetti, F., Storti, F., 2004. ${ }^{40} \mathrm{Ar}-{ }^{39} \mathrm{Ar}$ dating of pseudotachylytes: the effect of clast-hosted extraneous argon in Cenozoic faultgenerated friction melts from the West Antarctic Rift System. Earth Planet Sci. Lett. 223, 349-364. https://doi.org/10.1016/j.epsl.2004.04.042.

Di Vincenzo, G., Rossetti, F., Viti, C., Balsamo, F., 2013. Constraining the timing of fault reactivation: Eocene coseismic slip along a Late Ordovician ductile shear zone (northern Victoria Land, Antarctica). GSA Bullettin 125 (3/4), 609-624.

Dubbini, M., Cianfarra, P., Casula, G., Capra, A., Salvini, F., 2010. Active tectonics in northern Victoria Land (Antarctica) inferred from the integration of GPS data and geologic setting. J. Geophys. Res. 115, B12421.

Elliot, D.H., Larsen, D., Fanning, C.M., Fleming, T.H., Vervoort, J.D., 2017. The lower jurassic hanson formation of the transantarctic Mountains: implications for the antarctic sector of the gondwana plate margin. Geol. Mag. 154, 777-803.

Estrada, S., Läufer, A., Eckelmann, K., Hofmann, M., Gärtner, A., Linnemann, U., 2016. Continuous neoproterozoic to ordovician sedimentation at the east gondwana margin - implications from detrital zircons of the Ross orogen in northern Victoria Land, Antarctica. Gondwana Res. 37, 426-448.

Fagereng, Ake, Ikari J., Matt, 2020. Low-Temperature Frictional Characteristics of Chlorite-Epidote-Amphibole Assemblages: Implications for Strength and Seismic Style of Retrograde Fault Zones. Journal of Geophysical Research: Solid Earth 125 (4). https://doi.org/10.1029/2020JB019487.

Faulkner, D.R., Mitchell, T.M., Rutter, E.H., Cembrano, J., 2008. On the structure and mechanical properties of large strike-slip faults. Geological Society, London, Special Publications 299, 139-150.

Federico, L., Capponi, G., Crispini, L., 2006. The Ross orogeny of the transantarctic Mountains: a northern Victoria Land perspective. Int. J. Earth Sci. 95, 759-770.

Federico, L., Crispini, L., Capponi, G., 2010. Fault-slip analysis and transpressional tectonics: a study of Paleozoic structures in northern Victoria Land, Antarctica. J. Struct. Geol. 32, 667-684.

Ferraccioli, F., Bozzo, E., 2003. Cenozoic strike-slip faulting from the eastern margin of the Wilkes Subglacial Basin to the western margin of the Ross Sea Rift: an aeromagnetic connection. In: Storti, F., Holdsworth, R.E., Salvini, F. (Eds.), Intraplate Strike-Slip Deformation Belts, vol. 210. Geological Society, London, pp. 109-133. Special Publications.

Ferry, J.M., 1979. Reaction mechanisms, physical conditions and mass transfer during hydrothermal alteration of mica and feldspar in granitic rocks from south-central Maine, USA. Contrib. Mineral. Petrol. 68, 125-139.

Fitzgerald, J.D., Stünitz, H., 1993. Deformation of granitoids at low metamorphic grade I: reactions and grain size reduction. Tectonophysics 221, 269-297.

Fleming, T.H., Foland, K.A., Elliott, D.H., 1999. Apophyllite 40Ar/39Ar and Rb-Sr geochronology: potential utility and application to the timing of secondary mineralization of the Kirkpatrick Basalt, Antarctica. J. Geophys. Res. 104, 20081-20095.

Fondriest, M., Mecklenburgh, J., Passelegue, F.X., Artioli, G., Nestola, F., Spagnuolo, E., Rempe, M., Di Toro, G., 2020. Pseudotachylyte alteration and the rapid fade of earthquake scars from the geological record. Geophys. Res. Lett. 47 https://doi.org/ 10.1029/2020GL090020 e2020GL090020.
Franek, J., Schulmann, K., Lexa, O., 2006. Kinematic and rheological model of

exhumation of high pressure granulites in the Variscan orogenic root: example of the Blansky les granulite, Bohemian Massif, Czech Republic. Mineral. Petrol. 86, 253-276.

GANOVEX Team, 1987. Geological map of north Victoria Land, Antarctica, 1:500000explanatory notes. Geologisches Jahrbuch B 66, 7-79.

Gapais, D., 1989. Shear structures within deformed granites: mechanical and thermal indicators. Geology 17, 1144-1147.

Ghiribelli, B., Frezzotti, M.-L., Palmeri, R., 2002. Coesite in eclogites of the Lanterman Range (Antarctica): evidence from textural and Raman studies. Eur. J. Mineral 14, 355-360.

Gibson, G.M., 1984. Deformed conglomerates in the eastern lanterman range north Victoria Land, Antarctica. Geologisches Jahrbuch B 60, 117-141.

Gibson, G.M., 1987. Metamorphism and deformation in the Bowers Supergroup: implications for terrane accretion in northern Victoria Land, Antarctica. In: Leitch, E., Scheib- ner, E. (Eds.), Terrane Accretion and Orogenic Belts, vol. 19. Am. Geophys. Union, Geodyn. Ser., pp. 207-219

Gomes, M.E.P., Neiva, A.M.R., 2000. Chemical zoning of muscovite from the Ervedosa granite, northern Portugal. Mineral. Mag. 64, 347-358.

Goodge, J., 2020. Geological and tectonic evolution of the Transantarctic Mountains, from ancient craton to recent enigma. Gondwana Res. 80, 50-122.

Goodge, J.W., Fanning, C.M., Norman, M.D., Bennett, V.C., 2012. Temporal, isotopic and spatial relations of Paleozoic Gondwana-margin arc magmatism, central Transantartic Mountains, Antarctica. J. Petrol. 53, 2027-2065.

Gratier, J.P., Richard, J., Renard, F., Mittempergher, S., Doan, M.-L., Di Toro, G., Hadizadeh, J., Boullier, A.-M., 2011. Pressure solution creep as a mechanism of aseismic sliding in active faults: evidence from the San Andreas Fault Observatory at Depth (SAFOD). Geology 39, 1135-1138. https://doi.org/10.1130/G32073.1.

Grew, E.S., Sandiford, M., 1984. A staurolite-talc assemblage in tourmaline-phlogopitechlorite schist from northern Victoria Land, Antarctica, and its petrogenetic significance. Contrib. Mineral. Petrol. 87, 337-350.

Harlov, D., Wirth, R., 2000. K-feldspar-quartz and K-feldspar-plagioclase phase boundary interactions in garnet-orthopyroxene gneiss's from the Val Strona di Omegna, IvreaVerbano Zone, northern Italy. Contrib. Mineral. Petrol. 140, 148-162. https://doi. org/10.1007/s004100000185.

Harper, G.D., 1995. Pumpellyosite and prehnitite associated with epidosite in the Josephine ophiolite - Ca metasomatism during upwelling of hydro-thermal fluids at a spreading axis. In: Schiffman, P., Day, H.W. (Eds.), Low-Grade Metamorphism of Mafic Rocks, vol. 296. Geological Society of America Special Paper, Boulder, Colorado, pp. 101-122.

Hay, J., Hall, J., Simmons, G., Russell, M.J., 1988. Sealed microcracks in the Lewisian of NW Scotland: a record of 2 billion years of fluid circulation. J. Geol. Soc. 145, 819-830.

Heinicke, J., Fischer, T., Gaupp, R., Götze, J., Koch, U., Konietzky, H., Stanek, K.P., 2009. Hydrothermal alteration as a trigger mechanism for earthquake swarms: the Vogtland/NW Bohemia region as a case study. Geophys. J. Int. 178, 1-13.

Hielscher, R., Schaeben, H., 2008. A novel pole figure inversion method: specification of the MTEX algorithm. J. Appl. Crystallogr. 41, 1024-1037. https://doi.org/10.1107/ S002188980 8030112.

Holland, M., Urai, J.L., 2010. Evolution of anastomosing crack-seal vein networks in limestones: insight from an exhumed high-pressure cell, Jabal Shams, Oman Mountains. J. Struct. Geol. 32, 1279-1290.

Holness, M.B., 2003. Growth and albitization of K-feldspar in crystalline rocks in the shallow crust: a tracer for fluid circulation during exhumation? Geofluids 3, 89-102.

Janssen, C., Wirth, R., Rybacki, E., Naumann, R., Kemnitz, H., Wenk, H.-R., Dresen, G., 2010. Amorphous material in SAFOD core samples (San Andreas Fault): evidence for crush-origin pseudotachylytes? Geophys. Res. Lett. 37, L01303.

Kastner, M., Siever, R., 1979. Low temperature feldspars in sedimentary rocks. Am. J. Sci. 279, 435-479.

Kaur, P., Chaudhri, N., Hofmann, A.W., Raczek, I., Okrusch, M., Skora, S., Baumgartner, L.P., 2012. Two-stage, extreme albitization of A-type granites from Rajasthan, NW India. J. Petrol. 53, 919-948.

Kerrich, R., 1986. Fluid infiltration into fault zones: chemical, isotopic and mechanical effects. PAGEOPH 124, 225-268.

Kleinschmidt, G., Tessensohn, F., 1987. Early Paleozoic westward directed subduction at the Pacific margin of Antarctica. In: McKenzie, G. (Ed.), Gondwana Six: Structure, Tectonics and Geophysics, vol. 40. American Geophysical Union. Geophysical Monograph, pp. 89-105.

Kleinschmidt, G., Olesch, M., Rettmann, E.S., 1987. Ultramafic rocks of the lanterman range in north Victoria Land, Antarctica. Petrology, geochemistry and geodynamic implications. Geologisches Jahrbuch B 66, 231-273.

Kretz, R., 1983. Symbols for rock-forming minerals. Am. Mineral. 68, 277-279.

Läufer, A.L., Kleinschmidt, G., Henjes-Kunst, F., Rossetti, F. , Faccenna, C., 2006. Geological Map of the Cape Adare Quadrangle, Victoria Land, Antarctica, 1 : 250000. Pertusati, P.C., Roland, N.W. (Coord.), German-Italian Geological Antarctic Map Programme (GIGAMAP), BGR, Hannover.

Lee, M.R., Parsons, I., 1997. Dislocation formation and albitisation in alkali feldspars from the Shap granite. Am. Mineral. 557-570. VP.

Lin, A., 1996. Injection veins of crushing-originated pseudotachylyte and fault gouge formed during seismic faulting. Eng. Geol. 43, 213-224.

Lin, A., 2008. Crushing-origin pseudotachylyte and veinlet cataclastic rocks. In: Fossil Earthquakes: the Formation and Preservation of Pseudotachylytes. Lecture Notes in Earth Sciences, vol. 111. Springer, Berlin, Heidelberg. https://doi.org/10.1007/9783-540-74236-4_10. 
Lin, A., 2011. Seismic slip recorded by fluidized ultracataclastic veins formed in a coseismic shear zone during the 2008 Mw 7.9 Wenchuan earthquake. Geology 39, 547-550.

Lin, A., 2019. Thermal pressurization and fluidization of pulverized cataclastic rocks T formed in seismogenic fault zones. J. Struct. Geol. 125, 278-284.

Liou, J.G., Kim, Hyung Shik, Maruyama, S., 1983. Prehnite - epidote equilibria and their petrologic applications. J. Petrol. 24, 321-342.

Lisker, F., Läufer, A.L., 2013. The Victoria Basin: vanished link between Antarctica and Australia. Geology 41, 1043-1046.

Lisker, F., Läufer, A.L., Olesch, M., Rossetti, F., Schäfer, T., 2006. The Transantarctic Basin: new insights from fission track data and structural data from the USARP Mountains and adjacent areas (northern Victoria Land, Antarctica). Basin Res. 18, 497-520.

Lowenstern, J.B., 2001. Carbon dioxide in magmas and implications for hydrothermal systems. Miner. Deposita 36, 490-502.

Mainprice, D., Bachmann, F., Hielscher, R., Schaeben, H., 2015. Descriptive tools for the analysis of texture projects with large datasets using MTEX: strength, symmetry and components. In: Faulkner, D.R., Mariani, E., Mecklenburgh, J. (Eds.), Rock Deformation from Field, Experiments and Theory: A Volume in Honour of Ernie Rutter, vol. 409. Geological Society, London, pp. 251-271. Special Publications.

Malatesta, C., Crispini, L., Läufer, A., Lisker, F., Federico, L., 2018a. Effects of hydrothermal alteration during cycles of deformation along fault zones in granitoids (northern Victoria Land, Antarctica). AGU Fall Meeting Abstracts \#T11G-0231.

Malatesta, C., Federico, L., Crispini, L., Capponi, G., 2018b. Fluid-controlled deformation in blueschist-facies conditions: plastic vs. brittle behaviour in a brecciated mylonite (Voltri Massif, Western Alps, Italy). Geol. Mag. 155, 335-355.

McCaig, A.M., 1997. The geochemistry of volatile fluid flow in shear zones. In: Holness, M.B. (Ed.), Deformation-Enhanced Fluid Transport in the Earth's Crust and Mantle. Chapman \& Hall, London, pp. 227-266. Mineralogical Society Series 8.

Menegon, L., Pennacchioni, G., Spiess, R., 2008. Dissolution-precipitation creep of Kfeldspar in mid-crustal granite mylonites. J. Struct. Geol. 30, 565-579.

Menegon, L., Pennacchioni, G., Stünitz, H., 2006. Nucleation and growth of myrmekite during ductile shear deformation in metagranites. J. Metamorph. Geol. 24, 553-568.

Mittempergher, S., Dallai, L., Pennacchioni, G., Renard, F., Di Toro, G., 2014. Origin of hydrous fluids at seismogenic depth: constraints from natural and experimental fault rocks. Earth Planet Sci. Lett. 385, 97-109.

Mizoguchi, K., Hirose, T., Shimamoto, T., Fukuyama, E., 2007. Reconstruction of seismic faulting by high-velocity friction experiments: an example of the 1995 Kobe earthquake. Geophys. Res. Lett. 34, 1-3.

Molzahn, M., Wörner, G., Henjes-Kunst, F., Rocholl, A., 1999. Constraints on the Cretaceous thermal event in the Transantarctic Mountains from alteration processes in Ferrar flood basalts. Global Planet. Change 23, 45-60.

Moore, D., Byerlee, J.D., 1989. Textural development of clayey and quartzofeldspathic fault gouges relative to their sliding behavior. Phys. Chem. Earth 17, 1-9.

Morad, S., El-Ghali, M.A.K., Caja, M.A., Sirat, M., Al-Ramadan, K., Mansurbeg, H., 2010. Hydrothermal alteration of plagioclase in granitic rocks from Proterozoic basement of SE Sweden. Geol. J. 45, 105-116.

Nijland, T.G., Touret, J.L.R., 2001. Replacement of graphic pegmatite by graphic albiteactinolite-clinopyroxene intergrowths (Mjåvatn, southern Norway). Eur. J. Mineral $13,41-50$.

Palmeri, R., Talarico, F.M., Ricci, C.A., 2011. Ultrahigh-pressure metamorphism at the lanterman range (northern Victoria Land, Antarctica). Geol. J. 46, 126-136.

Passchier, C.W., Trouw, R.A.J., 2005. Microtectonics, second ed. Springer-Verlag, Heidelberg, pp. 1-366.

Pec, M., Stünitz, H., Heilbronner, R., Drury, M., de Capitani, C., 2012. Origin of pseudotachylites in slow creep experiments. Earth Planet Sci. Lett. 355, 299-310.

Pennacchioni, G., Mancktelow, N.S., 2018. Small-scale ductile shear zones: neither extending, nor thickening, nor narrowing. Earth Sci. Rev. 184, 1-12.

Pertusati, P.C., Ricci, C.A., Tessensohn, F., 2016. German-Italian geological antarctic map Programme - the Italian contribution. Introductory notes to the map case. Terra Antart. Rep. 15, 1-15.

Petersson, J., Eliasson, T., 1997. Mineral evolution and element mobility during episyenitization (dequartzification) and albitization in the postkinematic Bohus granite, southwest Sweden. Lithos 42, 123-146.

Philippot, P., Selverstone, J., 1991. Trace-element-rich brines in eclogitic veins: implications for fluid composition and transport during subduction. Contrib. Mineral. Petrol. 106, 417-430.

Philippot, P., van Roermund, H.L.M., 1992. Deformation processes in eclogitic rocks: evidence for the rheological delamination of the oceanic crust in deeper levels of subduction zones. J. Struct. Geol. 14, 1059-1077.

Phillips, G., Läufer, A., Piepjohn, K., 2014. Geology of the millen thrust system, northern Victoria Land, Antarctica. Polarforschung 84, 39-47.

Pour, A.B., Park, Y., Crispini, L., Läufer, A., Hong, J.K., Park, T.Y.S., Zoheir, B., Pradhan, B., Muslim, A.M., Hossain, M.S., Rahmani, O., 2019. Mapping listvenite occurrences in the damage zones of northern Victoria Land, Antarctica using ASTER satellite remote sensing data. Rem. Sens. 11, 1408. https://doi.org/10.3390/ rs11121408.

Ramsay, J.G., 1967. Folding and Fracturing of Rocks. McGraw Hill, New York.

Ricci, C.A., Talarico, F., Palmeri, R., Di Vincenzo, G., Pertusati, P.C., 1996. Eclogite at the antarctic palaeo-pacific active margin of gondwana (lanterman range, northern Victoria Land, Antarctica). Antarct. Sci. 8, 277-280.

Rice, J.R., 2006. Heating and weakening of faults during earthquake slip. J. Geophys. Res. 111, B05311. https://doi.org/10.1029/2005JB004006.

Rocchi, S., Capponi, G., Crispini, L., Di Vincenzo, G., Ghezzo, C., Meccheri, M., Palmeri, R., 2003. Mafic rocks at the wilson-bowers terrane transition and within the
Bowers terrane: implications for a geodynamic model of the Ross orogeny. Terra Antartica Rep. 9, 145-148.

Rocchi, S., Bracciali, L., Di Vincenzo, G., Gemelli, M., Ghezzo, C., 2011. Arc accretion to the early paleozoic antarctic margin of gondwana in Victoria Land. Gondwana Res. 19, 594-607.

Roland, N.W., Gibson, G.M., Kleinschmidt, G., Schubert, W., 1984. Metamorphism and structural relations of the Lanterman metamorphics. Geolische Jahrbuch B 60, 319-361.

Roland, N.W., Läufer, A.L., Rossetti, F., 2004. Revision of the terrane model of northern Victoria Land (Antarctica). Terra Antartica 11, 55-65.

Rossetti, F., Storti, F., Läufer, A.L., 2002. Brittle architecture of the Lanterman Fault and its impact on the final terrane amalgamation in north Victoria Land, Antarctica. Journal of the Geological Society London 159, 159-173.

Rossetti, F., Lisker, F., Storti, F., Läufer, A.L., 2003. Tectonic and denudation history of the Rennick graben (north Victoria Land): implications for the evolution of rifting between east and west Antarctica. Tectonics 22, 1016-1034.

Rossetti, F., Storti, F., Busetti, M., Lisker, F., Di Vincenzo, G., Läufer, A.L., Rocchi, S., Salvini, F., 2006. Eocene initiation of Ross Sea dextral faulting and implications for East Antarctic neotectonics. J. Geol. Soc. 163, 119-126. https://doi.org/10.1144/ 0016-764905-005.

Rowe, C.D., Kirkpatrick, J.D., Brodsky, E.E., 2012. Fault rock injections record paleoearthquakes. Earth Planet Sci. Lett. 335, 154-166.

Rusinov, V.L., 1965. On prehnite finds and the clastic nature of epidote in rocks of some areas of contemporary hydrothermal metamorphism. Izv. Akad. Nauk SSSR Ser. Geol. 2, 33-43.

Sacerdoti, M., Labernardiere, H., Gandais, M., 1980. Transmission electron microscope (TEM) study of geologically deformed potassic feldspars. Bull. Mineral. 103, $148-155$.

Saigal, G.C., Morad, S., Bjørlykke, K., Egeberg, P.K., Aagaard, P., 1988. Diagenetic albitisation of detrital K-feldspar in Jurassic, Lower Cretaceous and Tertiary clastic reservoir rocks from offshore Norway, I. Textures and origin. J. Sediment. Petrol. 58, $1003-1013$.

Salvini, F., Brancolini, G., Busetti, M., Storti, F., Mazzarini, F., Coren, F., 1997. Cenozoic geodynamics of the Ross Sea Region, Antarctica: crustal extension, intraplate strikeslip faulting and tectonic inheritance. Journal of Geophyscial Research 102 (24), 669-24,696.

Sánchez-Roa, C., Faulkner, D.R., Boulton, C., Jimenez-Millan, J., Nieto, F., 2017. How phyllosilicate mineral structure affects fault strength in Mg-rich fault systems. Geophys. Res. Lett. 44 https://doi.org/10.1002/2017GL073055.

Schulmann, K., Mlcoch, B., Melka, R., 1996. High-temperature microstructures and rheology of deformed granite, Erzgebirge, Bohemian Massif. J. Struct. Geol. 18 719-733.

Schüssler, U., Henjes-Kunst, F., Talarico, F., Flöttmann, T., 2004. High-grade crystalline basement of the northwestern Wilson Terrane at Oates Coast: new petrological and geochronological data and implications for its tectonometamorphic evolution. Terra Antartica 11, 15-34.

Shimamoto, T., Logan, J.M., 1981. Effects of simulated clay gouges on the sliding behavior of Tennessee sandstone. Tectonophysics 75, 243-255.

Sibson, R.H., 1977. Fault rocks and fault mechanisms. J. Geol. Soc. 133, 191-213.

Sibson, R.H., 1986. Brecciation processes in fault zones: inferences from earthquake rupturing. PAGEOPH 124, 159-175.

Sibson, R.H., 2000. Fluid involvement in normal faulting. J. Geodyn. 29 (3- 5), 469-499.

Simpson, C., Wintsch, R.P., 1989. Evidence for deformation-induced K-feldspar replacement by myrmekite. J. Metamorph. Geol. 7, 261-275.

Smeraglia, L., Billi, A., Carminati, E., Cavallo, A., Di Toro, G., Spagnuolo, E., Zorzi, F., 2017. Ultra-thin clay layers facilitate seismic slip in carbonate faults. Sci. Rep. 7, 664.

Spear, F.S., 1993. Metamorphic phase equilibria and pressure-temperature-time paths. Mineralogical Society of America Monograph Series I, 799.

Steffen, K., Selverstone, J., Brearley, A., 2001. Episodic weakening and strengthening during synmetamorphic deformation in a deep-crustal shear zone in the Alps. In: Holdsworth, R.E., Strachan, R.A., Magloughlin, J.F., Knipe, R.J. (Eds.), The Nature and Tectonic Significance of Fault Zone Weakening, vol. 186. Geological Society, London, pp. 141-156. Special Publications.

Storti, F., Rossetti, F., Läufer, A., Salvini, F., 2006. Consistent kinematic architecture in the damage zones of intraplate strike-slip fault systems in North Victoria Land, Antarctica and implications for fault zone evolution. J. Struct. Geol. 28, 50-63.

Storti, F., Salvini, F., Rossetti, F., Morgan, J.P., 2007. Intraplate termination of transform faulting within the Antarctic continent. Earth Planet Sci. Lett. 260, 115-126.

Stump, E., 1995. The Ross Orogen of the Transantarctic Mountains. Cambridge University Press, p. 284.

Sverdrup, E., Bjerlykke, K., 1997. Fault properties and the development of cemented fault zones in sedimentary basins: field examples and predictive models. NPF Special Publication 7. In: Muller-Pedersen, P., Koestler, A.G. (Eds.), Hydrocarbon Seals: Importance for Exploration and Production. Norwegian Petroleum Society (NPF), Singapore, pp. 91-106. Elsevier.

Talarico, F.M., Palmeri, R., Ricci, C.A., 2004. Regional metamorphism and pt evolution of the Ross orogen in northern Victoria Land (Antarctica): a review. Period. Mineral. 73, 185-196.

Tembe, S., Lockner, D.A., Wong, T.F., 2010. Effect of clay content and mineralogy on frictional sliding behavior of simulated gouges: binary and ternary mixtures of quartz, illite, and montmorillonite. J. Geophys. Res. 115, B03416. https://doi.org/ 10.1029/2009JB006383.

Tessensohn, F., 1984. Geological and tectonic history of the Bowers structural zone, north Victoria Land, Antarctica. Geologisches Jahrbuch B 60, 371-396. 
Tessensohn, F., 1994. The Ross Sea Region, Antarctica: structural interpretation in relation to the evolution of the southern Ocean. Terra Antartica 1, 553-558.

Tessensohn, F., Duphorn, K., Jordan, H., Kleinschmidt, G., Skinner, D., Vetter, U., Wright, T., Wyborn, D., 1981. Geological comparison of basement units in north Victoria Land, Antarctica. Geologisches Jahrbuch B 41, 31-88,

Tullis, J., 1983. Deformation of feldspars. In: Ribbe, P.H. (Ed.), Feldspar Mineralogy, vol. 2. Mineralogical Society of America, pp. 297-323. Reviews in Mineralogy.

Ujiie, K., 2007. Dynamics of earthquake faulting in subduction zones: inference from pseudotachylytes and ultracataclasites in an ancient accretionary complex. Sci. Drill. https://doi.org/10.2204/iodp.sd.s01.21.2007. Special Issue No. 1 (4): The Physics of Earthquake Rupture.

Vetter, U., Tessensohn, F., 1987. S- and I-type granitoids of Northern Victoria Land, Antarctica, and their inferred geotectonic setting. Geol. Rundsch. 76, 233-243.

Viana, R.R., Evangelista, H.J., Stern, W.B., 2007. Chemical zoning of muscovite megacrystal from the Brazilian Pegmatite Province. Anais da Academia Brasileira de Ciências (Annals of the Brazilian Academy of Sciences) 79, 431-439.
Voll, G., 1969. Klastische Mineralien aus den Sedimentserien der Schottischen Highlands und ihr schicksal bei aufsteigender Regional- und Kontaktmetamorphose. Habitationschrift. Technische Universitat Berlin.

Walker, B.C., 1983. The beacon supergroup of northern Victoria Land, Antarctica.- from. In: Oliver, R.L., James, P.R., Jago, J.B. (Eds.), Antarctic Earth Science. Australian Acad. Sci., Canberra, pp. 211-214.

Weaver, S.D., Bradshaw, J.D., Laird, M.G., 1984. Geochemistry of cambrian volcanics of the Bowers supergroup and implications for the early palaeozoic tectonic evolution of northern Victoria Land, Antarctica. Earth Planet Sci. Lett. 68, 128-140.

Wintsch, R.P., Christoffersen, R., Kronenberg, A.K., 1995. Fluid-rock reaction weakening of fault zones. J. Geophys. Res. 100 (B7), 13021-13032. https://doi.org/10.1029/ 94JB02622.

Wirth, R., Voll, G., 1987. Cellular intergrowth between quartz and sodium-rich plagioclase (myrmekite) - an analogue of discontinuous precipitation in metal alloys. J. Mater. Sci. 22, 1913-1918.

Wright, T.O., Ross, R.J., Repetski, J.E., 1984. Newly discovered youngest cambrian or oldest ordovician fossils from the Robertson Bay terrane (formerly precambrian), northern Victoria Land, Antarctica. Geology 12, 301-305. 